\title{
International Migration Experience and Entrepreneurship: Evidence from
}

\author{
Mexico \\ Forthcoming at World Development \\ Joshua Wassink \\ Office of Population Research, Princeton University. \\ 1-319-530-8284; jwassink@ princeton.edu
}

\begin{abstract}
This study investigates the effect of international migration experience on entrepreneurship in sending areas. To identify prosperous businesses that create jobs and encourage economic development, this study isolates businesses other than street-vending enterprises with non-family employees. Retrospective life history data from the Mexican Migration Project ( $\mathrm{N}=11,789$ persons \& 146,372 person-years) was used to estimate the annual probability of becoming an entrepreneur across 170 Mexican communities between 1975-2017. This study found that (1) any prior migration experience increases the probability of entrepreneurial entry relative to non-migrants; (2) accumulated months of migration experience are positively associated with the probability of entrepreneurial entry; (3) undocumented status is associated with a lower probability of entrepreneurial entry. The positive effect of accumulated migration experience on entrepreneurship suggests that international migrants can accumulate human and financial resources that are essential to early stage entrepreneurship. Thus, entrepreneurship represents an important pathway through which international migration can encourage economic development in less developed regions. At the same time, the results suggest that immigration policies in receiving countries can undercut migrants' capacities to mobilize resources and contribute to economic development upon return. These findings suggest that target migration creates a win-win by addressing labor shortages in receiving countries, while transferring resources to sending areas that enable economic mobility and development.
\end{abstract}

KEYWORDS: Entrepreneurship; Return migration; Accumulated migration experience; Capital constraints; Mexico 


\section{INTRODUCTION}

International migration, especially from less developed countries to more developed countries, provides a strategy by which resource-poor individuals and households can accumulate new human and financial capital in pursuit of economic mobility (Hagan et al., 2015; Stark, 1991; Stark \& Bloom, 1985). Resources accumulated abroad may provide critical inputs for would be entrepreneurs in less developed countries with inefficient credit markets and limited opportunities for occupational mobility (Caseiro \& Coelho, 2019; Gruenhagen et al., 2020; Hagan \& Wassink, 2020). By enabling business formation among returnees, cross-border movement could disrupt systems of inequality and contribute to economic development in sending regions (De Haas, 2010; Taylor, 2004). Indeed, Hausman and Nedelkoska (2018) recently found that return migration from Greece to Albania was associated with higher wages and employment among low-skilled Albanian non-migrants, a result they attributed to migrants' tendencies to invest remitted resources in new businesses upon return. ${ }^{1}$

Given the positive ripple effects of entrepreneurship in less developed areas, a large number of studies have explored the relationship between international migration and selfemployment among return migrants (for a recent review, see Gruenhagen et al., 2020). These studies find consistent evidence of a positive effect of migration experience on business formation, even after adjusting for potential unobserved selection bias (Hagan \& Wassink, 2020). However, substantial heterogeneity exists among self-employed return migrants. Some achieve economic prosperity through entrepreneurship, yet many others become self-employed as a last resort to avoid the vagaries of unemployment through marginal businesses (Wassink and

\footnotetext{
${ }^{1}$ Several other studies report similar positive economic impacts of return migration (Bucheli et al., 2019; Conover et al., 2018; Waddell \& Fontenla, 2015).
} 
Hagan 2018; Gruenhagen and Davidsson 2018; Hagan and Wassink 2020). Mezger Kveder and Flahaux (2012) suggest that fear of unemployment may be the most common reason for entering self-employment among returnees. More research is needed to evaluate the extent to which international migrants contributes to economic development through business formation and job creation.

This study uses large-scale data from the Mexican Migration Project (MMP) to isolate the effect of international migration on entrepreneurship. To do so, a restrictive definition of selfemployment is employed, which excludes all street vendors and includes only those businesses that employ at least one non-family worker. Businesses that meet these criteria yield significantly higher than average wages and, by definition, add jobs to their local communities (Gindling \& Newhouse, 2014; Maloney, 2004; Mandelman \& Montes-Rojas, 2009). After first measuring the effect of any U.S. migration experience and the probability of starting a business in Mexico, the analysis is then restricted to return migrants to evaluate how accumulated migration experience and undocumented status affect the probability of entrepreneurship. The results from these analyses reveal strong evidence that resources migrants accumulate while working abroad do increase their abilities to initiate new ventures in their origin communities. However, these positive effects are attenuated by undocumented status, revealing the consequences of immigration enforcement for global development.

The remainder of this paper is organized into 6 sections. Section 2 integrates literature on entrepreneurship, international migration, and economic mobility to contextualize the analysis and then reviews research on the relationship between international migration and selfemployment. Section 3 introduces the MMP data and describes the analytic sample. Section 4 presents descriptive and econometric analyses of the association between any U.S. migration 
experience and entrepreneurship in Mexico. Section 5 examines variations in entrepreneurship among return migrants by accumulated migration experience and legal status. Section 6 presents a set of robustness checks. Section 7 summarizes the findings and offers theoretical and policy considerations.

\section{BACKGROUND}

(a) Migration, Entrepreneurship, and Economic Mobility

Because of the precarious working conditions and low and stagnant wages that characterize jobs available to workers without college degrees throughout most low-to-middleincome countries (LMICs) (Huerta-Wong et al., 2013; Ravallion, 2014), self-employment (variously termed entrepreneurship, business formation, or occupational choice) is often the most viable pathway to economic mobility (Gindling \& Newhouse, 2014; Perry et al., 2007). In these

highly stratified contexts, business formation enables workers without access to professional jobs to maximize returns to their skills (Huerta-Wong et al., 2013; Portes \& Hoffman, 2003), and create new opportunities for their children (Castellani \& Lora, 2014). However, LMICs also tend to have inefficient credit markets and unequal access to formal training, which limit access to human and financial resources that enable successful business formation (Massey et al., 1993).

The entrepreneurship literature demonstrates the importance of financial and human capital for nascent entrepreneurs (Aldrich \& Wiedenmayer, 1991; Freeman et al., 1983). Founders require financial capital to secure workspace, equipment, and hire staff. Many businesses do not attain profitability in the short-term, leading their founders to draw down financial reserves still further (Fichman \& Levinthal, 1991). Beyond sufficient cash, small businesses depend on innovative products and sound business sense in order to operate 
efficiently and differentiate themselves in competitive markets (Alshanty \& Emeagwali, 2019; Caseiro \& Coelho, 2019). In particular, small businesses benefit when their founders exhibit openness to new ideas and creative organizational strategies (Franco \& Prata, 2019). In particular, Entrepreneurs that thrive in LMIC, which generally offer limited institutional protection for new founders, are commonly those willing to innovate and diversify their riskexposure in response to uncertainty (Gruenhagen et al., 2020; McCarthy et al., 2018).

For less educated individuals with limited financial resources, international migration offers a means of resource accumulation in anticipation of business formation (Dustmann \& Weiss, 2007; Stark \& Bloom, 1985). ${ }^{2}$ Indeed, the New Economics of Labor Migration (NELM) predicts that workers in countries with inefficient credit markets travel abroad to accumulate start-up capital, which they can invest in new businesses upon return (Lindstrom, 1996; Stark, 1991). Evidence suggests that migrants often organize their time abroad around a desired outcome upon return (Dustmann \& Kirchkamp, 2002). According to the NELM, international migration can enable financial capital accumulation and mobility via entrepreneurship in countries with limited occupational mobility and poorly functioning credit markets (Lindstrom \& Lauster, 2001; Massey \& Parrado, 1998; Stark, 1991).

Consistent with entrepreneurship research that documents the importance of founders' human capital for new businesses, other studies show that the non-financial human capital skills that migrants gain abroad can affect their opportunities for entrepreneurship upon return (Dustmann, 1999; Hernández-León, 2008). These studies aim to measure migrants' "total human

\footnotetext{
${ }^{2}$ From this perspective, higher destination wages may be offset by a preference for consumption in the sending country (Dustmann \& Weiss, 2007).
} 
capital," which includes formal schooling, but also informal learning in social and vocational settings (Findlay et al., 1996; Hagan et al., 2015; A. M. Williams, 2007), which could enhance their capabilities to achieve economic mobility upon return (Ayvar Campos \& Ochoa Lupián, 2015; de Haas, 2014). ${ }^{3}$ Some migrants learn new skills through formal job training and vocational programs, but many also gain these skills informally on the job through interaction with coworkers, close observation, practice, informal mentoring, and trial and error (D'Aubeterre Buznego, 2012; Grabowska, 2018; Hagan et al., 2015; Kumar et al., 2014; Lowe et al., 2010; Ramirez \& Hondagneu-Sotelo, 2009; Romero, 2012; Sánchez, 2013; A. M. Williams \& Baláž, 2005). Hagan and colleagues (2015) conceptualize the acquisition of these skills as "lifelong human capital formation" to capture both formal and informal learning across the life course. Perhaps more importantly, recent studies find that the application of skills learned abroad enables returnee entrepreneurs to innovate and gain competitive advantages over their non-migrant competitors (Gruenhagen \& Davidsson, 2018; Hagan \& Wassink, 2016).

Despite the potential for international migration to enable entrepreneurship among returnees, not all businesses started by former migrants are prosperous (Wassink \& Hagan, 2018). Throughout LMICs, which rarely provide sufficient social safety nets, self-employment offers an option of last resort among unemployed or marginally employed workers (Earle \& Sakova, 2000). For example, a study of Latin American workers found that although average self-employed workers earn more than their salaried counterparts, one third "appear to be [selfemployed] largely involuntarily; they would prefer formal jobs" (Perry et al., 2007, p. 6). Two exploratory studies recently highlighted similar differentiation among self-employed returnees. Gruenhagen and Davidsson (2018) found five distinct clusters of entrepreneurship orientations

${ }^{3}$ See Amartya Sen $(1988,1999)$ for a broad outline of the human capabilities approach. 
within a sample of Chinese return migrants. Three of the five groups were relatively less productive and indicative of necessity entrepreneurship. Similarly, Wassink and Hagan (2018) found that only $40 \%$ of the self-employed Mexican returnees in their sample could be classified as prosperous, while the remaining $60 \%$ were either survivalist (self-employed by necessity) or stepping-stone (actively looking for wage work).

In the current era of immigration control, heterogeneous migrant statuses can limit migrants' opportunities to accumulate new resources and achieve their goals (de Haas et al., 2019; Hagan et al., 2019; Roberts et al., 2017). Undocumented status, which applies to many migrants working throughout North America and Europe (de Haas et al., 2019), generally leads to precarious and exploitative working conditions (De Genova \& Peutz, 2010) and heightens the risk of unplanned expulsion (Cassarino, 2004; Roberts et al., 2017). Contemporary return migration flows include large numbers of deportees, rejected asylum seekers, and undocumented migrants who return home in response to harsh immigration policies in receiving countries (Medina \& Menjívar, 2015; Roberts et al., 2017). Because undocumented migration increases the risk of an unplanned return, it may reduce return migrants' preparedness and hinder their labor market reintegration and resource mobilization (Cassarino, 2004). Moreover, undocumented migrants also encounter lower earnings and more limited occupational mobility than their authorized counterparts (Hall et al., 2010), which likely limit their capacities to accumulate startup funds and gain new skills while abroad. Because undocumented migration lowers earnings potential and increases the risk of an unplanned return, it may be associated with a lower rate of entrepreneurship among returnees. 


\section{(b) Empirical Studies of Self-Employment among Return Migrants}

There is a large body of scholarship that investigates self-employment among return migrants in various global regions: Albania, Central America, Egypt, Mexico, Morocco, Senegal, Tunisia, and Turkey to name a few (Hagan \& Wassink, 2020). Many of these studies attempt to identify a potentially causal effect of international migration experience on the probability of becoming self-employed upon return. In general, these studies find that, after accounting for the potential endogeneity of occupational choice to the decision to migrate, international migration experience is positively associated with the probability of being self-employed among workers in sending areas (Démurger \& Xu, 2011; Dustmann \& Kirchkamp, 2002; McCormick \& Wahba, 2001; Mesnard \& Ravallion, 2006; Piracha \& Vadean, 2010). Three limitations, found throughout these studies, motivate the current analysis.

First, most studies of returnee entrepreneurship operationalize international migration experience as a dummy variable, thus ignoring the heterogeneous composition of international migrants. In one exception, Démurger and Xu (2011) found that repatriated savings were significantly associated with the odds of being self-employed in a sample of 86 return migrants in rural China. Hamdouch and Wahba (2015) reached a similar conclusion in their analysis of migration duration and self-employment among return migrants in Morocco, but they had no non-migrant control group with which to verify a baseline difference in self-employment rates between migrants and non-migrants. Mezger Kveder and Flahaux (2012) examined seven separate aspects of the migration experience, including migration duration, but lacked sufficient data with which to adjust for the endogeneity of migration or its component parts to migrants' occupational choices upon return (Dustmann \& Kirchkamp, 2002). By treating all migrants as a single homogenous group, studies neglect variations in their access to human and financial 
capital while abroad (Dustmann \& Kirchkamp, 2002; Wassink \& Hagan, 2018), which is essential to their abilities to launch new ventures upon return (Alshanty \& Emeagwali, 2019; McCarthy et al., 2018).

Second, most studies treat self-employment among return migrants and non-migrants as a single homogeneous category (Cruz \& Alfaro, 2018; Démurger \& Xu, 2011; Dustmann \& Kirchkamp, 2002; Mesnard, 2004; Mezger Kveder \& Flahaux, 2012), thus neglecting the disparate self-employment experiences documented among returnees (Gruenhagen \& Davidsson, 2018; Wassink \& Hagan, 2018). In one exception, Piracha and Vadean (2010) separated ownaccount and employer self-employment into separate categories and found that migration experience was significantly associated with both but had a much larger marginal effect on the probability of becoming an employer than on the probability of becoming an own-account worker. However, they did not disaggregate international migration experience to unpack the various mechanisms through which migration experience affects entrepreneurship upon return.

Third, despite the limitations imposed by undocumented status, few studies of returnee entrepreneurship assess the impact of legal status abroad on labor market mobility following return. Two recent qualitative studies found that unplanned returns limit migrants' opportunities to marshal resources in preparation for labor market re-entry upon return (Gubert \& Nordman, 2011; Hagan et al., 2019), and can push unprepared returnees into informal wage work or marginal self-employment as they struggle to find work in local labor markets (David, 2017; Mezger Kveder \& Flahaux, 2012). In his study of occupational mobility, Lindstrom (2013) found that being undocumented in the United States was associated with higher odds of downward 
occupational mobility upon return, but was unrelated to self-employment. ${ }^{4}$ Using data from the Mexican Census (1990-2010), Parrado and Gutierrez (2016) reveal a shift in the occupational profile of Mexican return migrants' away from entrepreneurship and formal salaried jobs toward informal sector day labor and marginal own-account work, which they attribute to increasingly punitive immigration enforcement policies in the United States. These studies raise the larger question: does legal marginality limit migrants' abilities to mobilize new resources in preparation for entrepreneurship upon return.

\section{(c) The Mexican case}

To overcome these three limitations, this study examines business formation in Mexico, a country with a long history of international migration. Throughout the latter half of the twentieth century, Mexican migration to the United States grew steadily, establishing itself as the largest binational labor flow in the world (Abel \& Sander, 2014). However, the Great Recession, changing demographic and economic characteristics in Mexico, and increased interior and border enforcement by the U.S. Government caused annual migration from Mexico to the United States to fall by 70\% between 2000 and 2010 (Hanson, 2009; Passel et al., 2012; Villarreal, 2014). These same factors escalated voluntary and forced return migration to Mexico. Between 2005 and 2014, 2.4 million Mexican immigrants returned home from the United States, more than double the number of returnees during the previous decade (Gonzalez-Barrera, 2015). Thus, even

\footnotetext{
${ }^{4}$ His measure of self-employment pooled own-account workers and employers, which may have masked contradictory effects of undocumented status on more marginal and more prosperous forms of self-employment.
} 
as Mexico-U.S. migration is no longer the largest emigrant flow in the world (Chishti \& Hipsman, 2015), U.S.-Mexico migration now outpaces all binational return flows by a wide margin — about four times the size of the second largest return flow, Indians returning from the United Arab Emirates, per recent estimates (Azose \& Raftery, 2019).

Mexico provides an ideal economic context within which to explore the development potential of international migration. On the one hand impressive economic growth over the last fifty years, resulting in its status as an upper-income country according to the World Bank (World Bank, 2003), provides opportunities for successful entrepreneurs to thrive (Gindling \& Newhouse, 2014; Maloney, 2004). On the other hand, Mexico remains extremely unequal, with limited access to professional occupations creating a strong incentive for workers with little formal schooling to pursue business formation (Alfaro, 2012; Huerta-Wong et al., 2013; Perry et al., 2007). Despite the obvious appeal of entrepreneurship, however, Mexico offers limited support for prospective entrepreneurs. Indeed, a 2018 report from the Global Entrepreneurship Monitor identifies Latin America as among the least supportive structural environments for early stage entrepreneurs, and the majority of businesses are self-financed (Castellani \& Lora, 2014). ${ }^{5}$ Within this constrained economic context, U.S.-migration offers an opportunity to earn higher wages and accumulate new skills, which could create opportunities for business formation and economic mobility among returning migrants (Hagan et al., 2015; Massey et al., 1993).

\footnotetext{
5 Throughout Latin America entrepreneurs rely on personal savings as the primary source of financing for their businesses (Kantis 2005).
} 


\section{DATA AND DESCRIPTIVE RESULTS}

(a) Mexican Migration Project

The MMP is a long-running survey of Mexican communities that collects detailed information about migration behavior, labor market activities, and other demographic processes. Every winter, since 1982, the MMP has collected random household samples in three to five Mexican communities. Although the communities are selected because they contain large proportions of emigrants and return migrants, the MMP sample has grown in size and representativeness over time. This study draws on the most recently available MMP170 file, which contains 27,274 households in 170 different communities, spread across 24 Mexican states. Although these data do not come from a national survey, Massey and Zenteno (2000) show that the MMP provides an accurate profile of Mexican migration to the United States when compared to the country's National Survey of Demographic Dynamics. Thus, while the MMP overrepresents communities in historic sending states, it provides a valid source from which to draw inferences about the experiences of Mexican migrants and the impacts of Mexican migration on sending communities.

The MMP is administered at the household level to about 200 households in each community. Data collection staff use both ethnographic and survey techniques to compile detailed information about household members and full labor market and migration histories for all household heads (Massey \& Zenteno, 2000). The longitudinal nature and size of the MMP is unique relative to other surveys that have been used to examine return migration and selfemployment, which are often cross-sectional and conducted in only a handful of communities (e.g., Démurger \& Xu, 2011; Hagan et al., 2015; Mesnard, 2004; Mezger Kveder \& Flahaux, 2012). This study uses information for all male household heads with non-missing information 
for the years 1975-2017. Women were excluded because men account for $86 \%$ of the household heads and more than $97 \%$ of household heads with U.S.-migration experience.

To capitalize on the MMP's life history design, the datafile was organized by person years, which correspond to rows in respondents' life histories. This structure facilitated the estimation of discrete time models predicting business formation among respondents who have not previously been self-employed. The analysis was restricted to working-age men between the ages of 25 and 50 years old - most Mexican migrants first travel abroad between the ages of 15 and 25 and most entrepreneurs start their businesses during mid-life (Fajnzlber et al., 2006; Fernandez-Huertas Moraga, 2010). ${ }^{6}$ This age cutoff also allows for the completion of higher education prior to workforce entry. ${ }^{7}$ Person-years during which respondents were in the United States were also censored. I also restricted the sample to $1975-2017$ for which there is complete contextual data available and to minimize recall bias in the retrospective life histories. Thus, the dataset includes male household heads aged 25-50 who lived in Mexico during 1975-2017 and had never been self-employed. ${ }^{8}$

${ }^{6}$ Entry into self-employment late in individuals' working lives is most commonly indicative of economic marginalization and job loss (Fajnzlber et al., 2006; Wassink \& Hagan, 2018). ${ }^{7}$ The MMP only measures current education for each household member so changes in educational attainment among respondents in their late teens are unobservable.

${ }^{8}$ Coefficients on key variables were substantively unchanged in models where the lower age bound was set at 20-years-old or 30-years-old. Similarly, the estimates were insensitive to adjusting the upper age limit to 45-years-old or 55-years-old. 
Respondents in the data file are observed once for each year that they were in Mexico from the age of 25 up until they become self-employed or turn 51. The sample included 146,372 person-years for 11,789 persons. About $14 \%(1,602)$ of the respondents migrated to and returned from the United States and $12.6 \%(18,458)$ of the person-years were lived by return migrantsi.e., persons currently living in Mexico who had previously worked in the United States. ${ }^{9}$ Years in which businesses were not started were coded as zero and years in which business formation occurred were coded as one.

\section{(b) Measuring entrepreneurship}

The MMP collects information about all businesses formed by respondents, including the year of formation, the number of non-family workers employed, and the industrial category. This information was used to identify prosperous businesses and exclude more marginal enterprises. Scholars commonly identify prosperous businesses in developing contexts as those with at least one paid employee (Gindling \& Newhouse, 2014; Mandelman \& Montes-Rojas, 2009; Parrado \& Gutierrez, 2016; Piracha \& Vadean, 2010). This definition was used, with one additional restriction. In their typology of return migrants' self-employment ventures, Wassink and Hagan (2018: 1082-3) observe that prosperously self-employed returnees' businesses "were located in establishments separate from their homes and often created new niches in the economy" as opposed to survivalist self-employed whose activities commonly included "ambulatory food and beverage stands." This distinction is consistent with research on marginal self-employment in

\footnotetext{
${ }^{9}$ Respondents who migrated to the United States prior to age 25 were coded as returnees for all years in which they were observed.
} 
Mexico and other less developed regions (Gindling \& Newhouse, 2014; Levy, 2008). Hence, entrepreneurship was defined as the presence of an enterprise other than street vending with at least one non-family worker. Because the MMP did not measure startup activity, entrepreneurship only included established businesses. Start-up activities were not observed.

\section{(c) U.S. migration experience}

Models with migrants and non-migrants included a dummy variable to dichotomously identify person-years in which respondents had previously worked in the United States to capture the effect of prior U.S. migration experience (Démurger \& Xu, 2011; Mezger Kveder \& Flahaux, 2012; Piracha \& Vadean, 2010). Subsequent analyses restricted to return migrants, included a continuous measure of migrants' cumulative years spent in the United States. Cumulative migration experience captures migrants' opportunities to accumulate new human and financial capital while abroad (Dustmann \& Kirchkamp, 2002; Hagan et al., 2015), which they can invest in new businesses upon return (Hamdouch \& Wahba, 2015; Wahba \& Zenou, 2012; Wassink \& Hagan, 2018). Research on entrepreneurship suggests a positive effect of migration experience on business formation, given the importance of human and financial capital to new enterprises (Alshanty \& Emeagwali, 2019; Freeman et al., 1983; Gruenhagen et al., 2020). To adjust for seasonal migration, which, in the Mexican case, suggests a pattern of migration primarily for consumption rather than investment (Garip, 2016), models also adjusted for the number of separate U.S. trips. These models also included a dummy variable that identified respondents who were undocumented on their last trips to the United States. Undocumented migration status, which is associated with lower wages while working abroad and lower preparedness upon return (Cassarino, 2004; Hall et al., 2010), is expected to be associated with a lower likelihood of 
entrepreneurship among returnees. The MMP did not directly measure mode of return (i.e., forced or voluntary).

\section{(d) Data description}

Table 1 summarizes individual, household, and community characteristics for the full sample and separately for non-migrant and return migrant person-years. Although the difference was only marginally significant $(p<0.1)$, U.S. migration experience was associated with a $35 \%$ higher annual probability of entering business formation ( $0.46 \%)$ relative to non-migrant personyears $(0.34 \%)$. Thus, the descriptive data suggests a possible edge in entrepreneurship among return migrants, consistent with previous research (Hagan \& Wassink, 2020).

[Table 1 about here]

There was a modest difference in age by migrant status. Return migrants were significantly less educated than non-migrants, which is consistent with patterns of negative selection into U.S. migration among Mexican workers (Rendall \& Parker, 2014). Return migrants were slightly more likely than non-migrants to be married, but tended to have fewer children, perhaps reflecting delayed family formation due to separation between migrant breadwinners and left-behind spouses. Return migrants were also far more likely to have migrant fathers, indicative of the familial networks that often enable international migration (Massey et al., 1993). Return migrants' households owned significantly more properties and land parcels than non-migrants' households, a pattern consistent with the wealth accumulation commonly observed among international migrants (Garip, 2012, 2014). Finally, consistent with welldocumented patterns of Mexican migration (Masferrer \& Roberts, 2012; Rendall \& Parker, 
2014), return migrants disproportionately resided in rural areas with fewer than 15,000 inhabitants, while non-migrants were more evenly distributed across community types.

(4) HOW DOES MIGRATION EXPERIENCE AFFECT ENTRY INTO SELFEMPLOYMENT

Binomial Probit models were estimated to analyze the association between international migration experience and business formation. To contextualize these models, Table 2 summarizes respondents' characteristics in the years that they became entrepreneurs as opposed to all other years. All the independent variables are observed in the year immediately prior to entry into entrepreneurship. Thus, the column for entrepreneur characterizes respondents in the year preceding business formation-i.e., characteristics of founders. The proportion returnee was significantly higher among those soon to become entrepreneurs, providing additional descriptive evidence of the relationship between migration experience and business formation. Entrepreneurs also tended to be well-educated, reflecting positive skill selection (Caseiro \& Coelho, 2019; Fajnzlber et al., 2006; Wassink \& Hagan, 2018). The educational gradient persisted among return migrants—returnee entrepreneurs averaged 8.5 years of schooling, compared to just 6.4 years among other return migrants.

\section{[Table 2 about here]}

Entrepreneurs were on average slightly younger than non-entrepreneurs and had fewer children, reflecting the tendency to initiate new businesses relatively early in the working life cycle (Fajnzlber et al., 2006; Wassink \& Hagan, 2018). Entrepreneurs also had fewer properties and land parcels. Respondents most commonly started new businesses in mid-size towns and small urban areas but were less likely to engage in entrepreneurship in rural ranchos. The 
tendency for entrepreneurs to locate in mid-size areas likely reflects the need for some infrastructure, which may rule out more rural areas (Gindling \& Newhouse, 2014; Wassink, 2018; Wassink \& Hagan, Forthcoming). Table 2 reveals that the bivariate association between U.S. migration experience and business formation existed despite migrants having several characteristics — older, fewer years of schooling, and rural residence - that are inversely related to entrepreneurship.

\section{(a) Econometric specification}

The key outcome of interest in the first stage of analysis is the relationship between the probability $\left(Y_{i t}^{*}\right)$ that an individual $i$ will form a business in year $t$ and a dummy variable that identifies whether or not individual $i$ has previously worked in the United States in year $t$. Because, the latent probability of business formation depends on unobserved factors such as individual $i$ 's entrepreneurial ability and risk tolerance, we cannot directly estimate $Y_{i t}^{*}$. Thus, the specified model captures the observed probability that individual $i$ enters self-employment in year $t+1\left(Y_{i t+1}\right)$. This model takes the following form:

$Y_{i t+1}=\beta_{0}+\beta_{n} X_{i t}+R_{i t}+u_{i t} \quad, \mathrm{t}=1,2, \ldots \mathrm{T}$

where $R_{i t}$ dichotomously indicates whether or not individual $i$ migrated to and returned from the United States as of year $t, X_{i t}$ includes the individual, household, and community-level characteristics shown in Table 1 , and $u_{i t}$ is a randomly distributed error term (Probit model). ${ }^{10}$

\footnotetext{
${ }^{10}$ In the estimated Probit models, standard errors were clustered at the community level. Models in which the standard errors were clustered at the individual level were substantively identical.
} 
In the naïve model, international migration experience is assumed to be exogenous to business formation. However, evidence suggests that international migrants are self-selective on unobservable characteristics that may also affect occupational choice (Dustmann, 2001). Perhaps not surprisingly, scholars identify high levels of risk-taking and resiliency within migrant groups (Hagan et al., 2015; Obschonka et al., 2018), qualities known to increase entrepreneurial behavior (Caseiro \& Coelho, 2019). Perhaps more importantly, if international migration is viewed as a strategy to accumulate a target sum of money to then invest in a business (Lindstrom, 1996; Stark, 1991), then migration would necessarily be endogenous to occupational choice upon return. An appropriate strategy to account for this potential endogeneity is the estimation of a recursive bivariate Probit model that first estimates the probability of being a return migrant and then estimates the probability of becoming self-employed (Greene, 2008; Wooldridge, 2002). In the first stage, the decision to migrate and return can thus be estimated as the following probit model:

$R_{i t}^{*}=\beta_{0}+\beta_{n} X_{i t}+\beta_{n} Z_{i t}+u_{i t} \quad, \mathrm{t}=1,2, \ldots \mathrm{T}$

where $R_{i t}^{*}$ is a latent variable associated with the probability that individual $i$ migrated and returned prior to year $t, x_{i t}$ is a battery of time-varying individual, household, and community-level characteristics, $u_{i t}$ is a randomly distributed error term, and $Z_{i t}$ is a set of instrumental variables that predict the probability of migrating and returning prior to year $t$, and are excluded from the second-stage model. Good instruments should be strongly associated with the endogenous predictor, but should not have an unobserved relationship with the outcome variable (Greene, 2008).

From the migration literature, two instruments were selected: local migrant networks and local migrant networks squared. Migrant networks are commonly used to instrument for 
international migration in research on economic development in sending communities (Démurger \& Xu, 2011; Piracha \& Vadean, 2010; Woodruff \& Zenteno, 2007). Migration networks affect the probability of migration in two ways. First, they raise the subjective cost of not migrating by increasing non-migrants' deprivation relative to their migrant peers (Stark \& Taylor, 1989). Second, they lower the objective costs of migrating through the dissemination of information about how to cross the border and potential employment opportunities in destination communities (Singer \& Massey, 1998). The community-level prevalence of international migration was observed when respondents were 15 -years old. ${ }^{11}$ Measuring migration prevalence at 15 -years-old locates these instruments temporally proximate to the common life period of a first labor migration and distant from potential first entry into self-employment.

\section{(b) Regression results comparing migrants and non-migrants}

Table 3 presents results from naïve probit models and the recursive bivariate probit model predicting business formation within the full sample. The selected instruments performed well in the model. One important qualification for instrumental variables is that they do not affect the outcome variable except through the endogenous variable included in the second stage regression (Angrist et al., 1996). As shown in Column 2, neither instrument was significantly associated with entrepreneurship (their p-values were 0.654 and 0.594 respectively). However, as

\footnotetext{
${ }^{11}$ Massey et al. (1994) define the prevalence ratio as the annual proportion of all living community residents older than 15 who have previously migrated to the United States. They show that migration becomes less selective on education as the prevalence ratio increases, suggesting that it is indeed associated with a lower cost of migrating.
} 
the first-stage probit model (column 3) shows, the instruments were strongly associated with the probability of being a return migrant, with a joint F-statistic of $153(\mathrm{p}<0.001)$. The Wald test of exogeneity failed to reject the null hypothesis that the error term from the first stage was uncorrelated with the error term from the second stage regression $(\mathrm{p}=0.319)$. The non-significant Wald test indicates that endogeneity may not be cause for serious concern in the case of MexicoU.S. migration and business formation, a conclusion that is consistent with studies of migration and business formation in other countries and with research on U.S.-migration and wealth accumulation in Mexico (Démurger \& Xu, 2011; Garip, 2012; Mesnard, 2004).

\section{[Table 3 about here]}

The naïve and two-step estimation results revealed a positive association between international migration experience and the probability of business formation once other demographic and contextual characteristics were considered. Although the estimate was less stable in the recursive model, which resulted in a coefficient that was only significant at the 0.1 level, the magnitude of the returnee coefficient increased after adjustment for selection, a result consistent with the descriptive and naïve probit analyses. ${ }^{12}$ Moreover, the lack of evidence for endogeneity suggests that the naïve probit estimates can be safely interpreted as revealing a statistically significant positive relationship between prior U.S. migration experience and the probability of becoming an entrepreneur in Mexico.

The other variables in the model generally operated as expected. Although they were not statistically significant, the coefficients on age and age-squared suggest a curve-linear

\footnotetext{
${ }^{12}$ Démurger and Xu (2011) also found a larger coefficient in their two-step model of selfemployment relative to their naïve Probit estimate.
} 
relationship, consistent with life cycle models of self-employment. Educational attainment increased the odds of entrepreneurship, highlighting the importance of human capital skills for business formation. The number of children was inversely correlated with entrepreneurship, perhaps indicating the financial pressure to provide, which could discourage long-term investments such as business formation. ${ }^{13}$ Having a migrant father was initially positively associated with entrepreneurship, but this relationship dropped out after adjustment for migrant networks and selection into migration. As in the descriptive analysis, residence in small cities was positively associated with the probability of business formation.

These results corroborate previous studies conducted without instrumental variables or other econometric identification strategies that also reveal positive associations between international migration migration experience and business formation in sending countries (Démurger \& Xu, 2011; Mesnard, 2004; Wahba \& Zenou, 2012). They also extend work by Piracha and Vadean (2010), by providing a second regional example in which international migration experience is positively associated with employer self-employment, suggesting that self-employment among return migrants is more than just a product of a stalled labor market reentry among returnees (Mezger Kveder \& Flahaux, 2012). The positive association between return migration and entrepreneurship has important implications for economic development given recent evidence that return migration leads to economic growth and higher wages in origin communities (Hausmann \& Nedelkoska, 2018; Waddell \& Fontenla, 2015).

${ }^{13}$ The negative coefficient could also capture the timing of business formation, which tends to occur relatively early in the family formation process. 


\section{(5) ENTREPNRENEURSHIP BY MIGRATION DURATION AND LEGAL STATUS}

To better understand how migration experience affects entry into entrepreneurship, a second set of models was estimated using only person-years lived by return migrants. These models incorporated aspects of migration experience expected to affect the probability of becoming an entrepreneur. First, Figure 1 shows the distribution of accumulated months of U.S. migration experience and the proportion undocumented among returnees by entrepreneurial status. As the figure shows, entrepreneurship was associated with a sizeable premium in terms of accumulated months of U.S. experience. Relative to other returnees, entrepreneurs were also significantly less likely to be undocumented while working in the United States. These bivariate associations are consistent with the expectation that cumulative migration experience increases entrepreneurial capacity while undocumented status reduces it.

[Figure 1 about here]

To assess the association between accumulated U.S. experience, legal status, and business formation, the following probit model can be written:

$$
Y_{i t+1}=\beta_{0}+\beta_{n} X_{i t}+\operatorname{USexp}_{i t}+\text { Undoc }_{i t}+\text { UStrips }_{i t}+u_{i t} \quad, \mathrm{t}=1,2, \ldots \mathrm{T}
$$

where $U S \exp _{i t}$ is a continuous variable that measures the total number of months that each return migrant was in the United States. The model also includes a dummy variable that indicates whether or not each respondent worked in the United States without authorization on their most recent trip $\left(U_{\left.n d o c_{i t}\right)}\right)$ and a continuous variable $\left(\right.$ UStrips $\left._{i t}\right)$ that counts each respondents' number of separate U.S. visits. ${ }^{14}$ In Eq. 3, the effect of accumulated migration experience is

\footnotetext{
${ }^{14}$ Migrants who entered the United States legally with tourist visas, but subsequently worked in the United States ( $80 \%$ of tourist visa entrants in the sample) were treated as undocumented
} 
assumed to be exogenous to business formation. Yet, theoretical considerations question the validity of that assumption. If individuals migrate abroad with the goal of starting a business upon return, then their migration duration is presumed to be endogenous to their eventual occupational choice (Dustmann \& Kirchkamp, 2002; Dustmann \& Weiss, 2007). Specifically, evidence suggests that migrants who plan to start businesses in their sending countries may strategically extend their time abroad to accumulate the resources necessary for business formation upon return (Lindstrom, 1996). Thus, estimating Eq. 3 without considering the potential endogeneity of $U S \exp _{i t}$ to $Y_{i t+1}$ could yield biased estimates.

To adjust for the potentially endogenous relationship between cumulative migration experience and entrepreneurship, a two-step probit model with instrumental variables was estimated. Following several previous studies, the first IV considered was age at first migration (Démurger \& Xu, 2011; Mesnard, 2004). Migrants who depart at earlier ages can be expected to spend longer abroad because of their earlier life stage and potentially have more limited family ties in sending communities (Massey et al., 1993). However, evidence from Mexico suggests that age at first migration is not exogenous to business formation. In their analysis of selfemployment among Mexican returnees, Wassink and Hagan (2018) found that those who depart later in life are more likely to migrate in response to marginal labor market statuses in their home communities and are less likely to start prosperous businesses upon return. ${ }^{15}$ When included as

because working violates their visas, which exposes them to the risk of detention and deportation encountered by those who entered the United States without authorization.

${ }^{15}$ Wassink and Hagan (2018: 1090) write: "the survivalist self-employed tended to migrate based upon a neoclassical rationale ... Their transitions - both into migration and subsequently 
an independent variable along with accumulated U.S.-experience, age at first migration was significantly and negatively associated with the probability of entering entrepreneurship, indicating that it violates the exclusion restriction (Greene, 2008).

Thus, a second instrument, the total dollar value of the U.S. border patrol budget in constant 2010 U.S. dollars, was identified. Steady growth in the U.S. immigration enforcement budget, which began with the passage of the Immigration Reform and Control Act (IRCA) in 1986, has had the unintended consequence of significantly extending the time that Mexican migrants spent in the United States (Massey et al., 2016). Border enforcement necessitated the use of smugglers to cross the border without authorization and significantly increased the risk of physical harm by pushing undocumented entrants away from popular crossing areas such as the Tijuana-San Diego border toward the Sonora desert (Massey et al., 2016). These changes led to steep increases in the dollar cost of entry into the United States and heightened the risk of personal injury or death while crossing (Massey et al., 2016). While rising enforcement did render seasonal unauthorized migration economically infeasible, it had the unintended consequence of encouraging migrants to remain in the United States long-term rather than spending part of each year in Mexico (Garip, 2016; Massey et al., 2016). Thus, an indicator of annual border enforcement provides a second possible instrument for accumulated U.S. migration experience.

into self-employment — reveal a pattern of labor market marginalization that pushes informal sector workers, especially those later in their careers with few marketable skills, to attempt multiple mobility strategies in response to persistently blocked mobility [emphasis added]." 
Figure 2 plots the associations between these two potential instruments and accumulated months of U.S. experience. On the left, rising investment in border security (here measured as the dollar value of the U.S. border patrol budget) observed when respondents were 15 years old, was associated with a steady increase in the average number of months spent in the United States. That is, the more money the United States allocated to the border patrol budget, the longer Mexican migrants remained in the United States. On the right, age at first migration was inversely correlated with accumulated U.S. experience. In other words, migrants who left for the United States later in life accumulated less total U.S. experience. After testing various specifications, two instruments were selected based on these variables: the border patrol budget at age 15 and the U.S. border patrol budget at age 15 interacted with age at first migration. The baseline coefficient on age at first migration was omitted from the first stage regression model to avoid violating the exclusion criterion (Greene, 2008).

[Figure 2 about here]

Table 4 presents results from naïve Probit models (Model 1 through Model 4) and the two-stage probit model predicting the probability of entry into entrepreneurship among Mexican return migrants. A lingering concern was that the border patrol instrument, which increased over time, could have been confounded by period changes that may have also affected opportunities for business formation in Mexico. ${ }^{16}$ If period changes related to business formation then the instrument would violate the exclusion criterion (Angrist et al., 1996). Therefore, after estimating naïve Probit models without and then with the instruments as independent variables (Model 1

\footnotetext{
16 The correlation between the U.S. border patrol budget at age 15 and the year of observation was 0.51 .
} 
and Model 2), two additional models were estimated. Model 3 included dummy variables that captured key periods in Mexico-U.S. migration (Massey et al., 2016), the post-IRCA period and the post-2001 period. Model 4 included a continuous measure of year of observation. Neither of the instruments included in Model 2 nor the period effects in Model 3 and Model 4 were significantly associated with the probability of starting a business, suggesting that the instruments provide valid exogenous regressors (Greene, 2008). The F-statistic from the first stage regression confirmed the strength of the exogenous regressors, which was suggested by the patterns in Figure 2. Finally, the Wald test of exogeneity did not reject the null hypothesis that accumulated U.S. migration experience was unrelated to occupational choice upon return, suggesting that endogeneity did not significantly bias the estimated relationship between accumulated U.S. experience and business formation in Mexico.

[Table 4 about here]

The naïve probit models all pointed to a strong positive association between accumulated U.S. migration experience and business formation among Mexican return migrants. Results from the two-step model with exogenous regressors confirmed the positive effect of accumulated U.S. experience on entrepreneurship in Mexico. Predicted probabilities of annual business formation were calculated using results from the two-step probit model to quantify the impact of accumulated U.S. experience on entrepreneurship in Mexico. These probabilities ranged from $0.35 \%$ at the $10^{\text {th }}$ percentile (12-months) to $0.41 \%$ at the median (36 months) to $0.68 \%$ at the $90^{\text {th }}$ percentile (108 months). Recall that the annual probability of business formation among nonmigrants was $0.34 \%$ (Table 1). Thus, migrants with little U.S. experience are no different from non-migrants in terms of entrepreneurship, but high levels of accumulated U.S.-migration experience can double the probability of becoming an entrepreneur. This result is consistent with 
previous research finding that migrants' accumulated resources predict self-employment in rural China (Démurger \& Xu, 2011) and that international migration experience is strongly associated with entrepreneurial self-employment in Albania (Piracha \& Vadean, 2010).

The models also found a negative association between working in the United States without authorization and the probability of business formation in Mexico. The estimated association between undocumented status and business formation is not causal. It is possible, for example, that unauthorized migrants who are deported opt out of business formation in Mexico not because they lack the resources, but because they intend to re-join family members living in the United States (Martínez et al., 2018). It could also be the case that migrants who obtain legal authorization share certain characteristics with successful entrepreneurs, such as more education and skills (Massey et al., 1993). However, given the high rate of deportations over the last two decades and the lower wages earned by undocumented migrants in the United States (Hall et al., 2010; Roberts et al., 2017), the negative coefficient on undocumented status is consistent with theoretical expectations, namely that undocumented status increases the risk of an unplanned return and reduces migrants' resource accumulation capacity (Cassarino, 2004). Both these factors are expected to negatively correlate with entrepreneurship. The negative coefficient on the number of U.S. trips is consistent with the expectation that circular migrants act as incomemaximizers (Garip, 2016) and are less likely to start businesses upon return. Yet, the number of U.S.-trips did not reach statistical significance in any of the models- the null hypothesis that U.S. trips is unrelated to entrepreneurship cannot be rejected. The demographic and control variables yielded coefficients consistent with the full model that included non-migrants, revealing entrepreneurial behavior among return migrants that is consistent with the general population. In other words, the similar coefficients paired with the implementation of two-step 
identification strategies, suggest that entrepreneurship upon return is less a product of selective entry into migration, and more the result of resource accumulation while abroad.

\section{ROBUSTNESS CHECKS}

Instrumental variables studies rely on the exclusion restriction, which states that the instrument does not have a direct effect on the outcome except for the indirect effect via the predictor of interest (Angrist et al., 1996). Although the exclusion criterion is not empirically verifiable, below I consider some threats to the instruments used here and then describe additional analyses that were conducted to assess their validity. There is some evidence that international migration is associated with community wealth accumulation, which can promote business formation in areas with well-established migration networks (Woodruff \& Zenteno, 2007). If migration networks are associated with more favorable business contexts, then it could introduce upward bias into the second-stage results for which migration networks were used as an exogenous regressor. To examine this possibility, I replicated the main regression models shown in Table 3 and Table 4 with a control for the proportion of respondents who were entrepreneurs in year $t$. The proportion of entrepreneurs captures the business climate in survey communities to adjust for the economic benefits of migration networks. These results are in Table A1 (full sample) and Table A2 (migrants only) in the appendix.

The proportion of entrepreneurs had a positive and highly significant association with the probability of becoming an entrepreneur in year $t+1$, indicating that it provides a good indicator of the local entrepreneurial context. Also, Table A2 shows that the proportion entrepreneur was positively associated with migration duration, which is consistent with research on the relationship between time spent abroad and investment opportunities at home (Lindstrom, 1996). 
However, none of the key associations (returnee, accumulated U.S. experience, or legal status) changed in direction or statistical significance and all the instruments remained valid based on the Wald tests of exogeneity. Indeed, the effects of being a returnee (Table A1) and accumulated migration experience (Table A2) increased in magnitude and statistical significance after adjusting for the proportion entrepreneur, suggesting that the models presented in the text may underestimate the true effect of migration experience on entrepreneurial capacity. These analyses support a causal interpretation of the positive associations between being a return migrant, accumulated migration experience, and the probability of entrepreneurial entry upon return.

\section{CONCLUSION}

This study examined whether international migration can enable entrepreneurship and job creation in sending regions. Understanding the link between international migration and business formation has broad implications for economic development. Not only do entrepreneurs create jobs and expand their local economies, self-employment also provides an important economic mobility pathway for workers with little schooling. A recent journal issue on self-employment and social mobility throughout Latin America found that among workers from middle- and lower-class backgrounds, self-employment consistently increased rates of intra- and intergenerational mobility relative to wage labor (Castellani and Lora 2014). At the same time, less developed regions of the globe including Latin America offer limited structural support for early stage entrepreneurs. ${ }^{17}$

${ }^{17}$ The Inter-American Development Bank estimates that $80 \%$ of Latin American entrepreneurs use personal savings as the primary source of financing for their businesses (Kantis 2005). 
Recursive bivariate probit models found evidence that after adjusting for potential unobserved heterogeneity, international migration increases the probability of forming a new business. This study improved upon previous research by adopting a restrictive definition of entrepreneurship that excludes own-account workers and street vendors. Thus, the results suggest that migration experience enables the formation of prosperous businesses that create jobs in returnees' local communities (Piracha \& Vadean, 2010; Wassink \& Hagan, 2018). However, modeling the relationship between any migration experience and business formation sheds little insight on the mechanisms by which working abroad contributes to business formation at home.

Research on entrepreneurship suggests that international migration could provide sending households with much needed human and financial capital with which to overcome the liability of newness inherent to nascent enterprises (Fichman \& Levinthal, 1991; Freeman et al., 1983). Following evidence that migrants gradually accumulate new skills and savings, which could be invested in businesses upon return (Gruenhagen et al., 2020; Hagan et al., 2015), a measure of cumulative migration experience was constructed as a proxy for international resource accumulation. Results from a recursive bivariate probit model found that as return migrants accumulate more foreign experience, their probability of future business formation increases. This dose-response approach suggests that international migration can provide access to human and financial resources, which are vital to business formation (Alshanty \& Emeagwali, 2019; Franco \& Prata, 2019; Massey \& Parrado, 1998), a result that confirms recent exploratory studies of returnee entrepreneurship (Gruenhagen \& Davidsson, 2018; Wassink \& Hagan, 2018).

At the same time, the results suggest that immigration enforcement policies in receiving societies can attenuate the development potential of international migrants. Undocumented status was associated with a significant decline in the annual probability of business formation upon 
return. Although the association between legal status and entrepreneurship was not causal, the negative association points to the potential consequences of poor working conditions, low wages, and the risk of deportation and unplanned return among undocumented workers in the United States (Hall et al., 2010; Roberts et al., 2017). This finding suggests that policies of immigration control and deportation, which have proliferated throughout migrant destination countries in North America and Europe (Hollifield et al., 2014), can undercut migrants' capacities to mobilize resources and contribute to economic development upon return to sending areas (Cassarino, 2004).

This study has three important limitations, which can motivate future research on international migration and economic development. First, studies that rely on instrumental variables can never completely verify that they meet the exclusion criterion. The most robust analyses leverage natural and planned experiments to generate effectively causal results (McKenzie et al., 2010). Given that such experiments are rare in the context of international movement, future studies should seek to replicate these findings in different contexts and using different instruments or identification strategies. Second, scholars find substantial variations in entrepreneurship across local and national contexts (Gindling \& Newhouse, 2014; Wassink, 2018). Thus, the results for Mexico, and upper-middle-income country with a high rate of entrepreneurship (GEM, 2016), may differ from those in poorer and less developed countries. Indeed, a recent qualitative study suggests that the returns to international migration diminish in rural and undeveloped communities (Wassink \& Hagan, Forthcoming). Future studies might adopt a comparative lens to ascertain how local and national context shapes entrepreneurial behavior among returnees (Hagan \& Wassink, 2020). Third, based on the available survey measures, this study adopted a relatively course proxy for financial and human capital 
accumulation (total migration experience). Future data collection efforts might include explicit survey items to more precisely capture the process of resource accumulation among international migrants (e.g., Hagan \& Wassink, 2016; A. Williams \& Baláž, 2014). These measures could be used to integrate entrepreneurship research with migration policy to encourage economic development in migrant-sending areas.

Despite these limitations, this study has several implications for policy. In Mexico and other sending countries (Démurger \& Xu, 2011; Mesnard, 2004), local and national governments might leverage the development potential of returning migrants through supporting the investment of resources accumulated abroad in new businesses upon return. Mexico, for example, has a well-documented history of encouraging remittances targeted toward local development projects (Fitzgerald, 2008). However, its programs to support the reintegration of return migrants remain limited. In informational interviews conducted with return migrants conducted as a part of the fieldwork for this project, no respondents reported participation in (or even awareness of) government programs intended to support former migrants' reintegration into their sending communities. Through proactive policies of return, sending country governments could seek to harness the development potentials of their diaspora by encouraging and supporting the investment of accumulated resources in entrepreneurial ventures in underdeveloped sending areas.

\section{REFERENCES}

Abel, G. J., \& Sander, N. (2014). Quantifying Global International Migration Flows. Science, 343(6178), 1520-1522. https://doi.org/10.1126/science.1248676 
Aldrich, H. E., \& Wiedenmayer, G. (1991). From traits to rates: An ecological perspetive on organizational foundings. In J. Katz \& R. Brockhaus (Eds.), Advances in entrepreneurship, firm emergence, and growth (pp. 145-195). JAI Press.

Alfaro, R. S. (2012). Actividades productivas y migración internacional de retorno: Los panaderos de San Miguel Coatlán, Oaxaca. Descatos, 41, 107-122.

Alshanty, A. M., \& Emeagwali, O. L. (2019). Market-sensing capability, knowledge creation and innovation: The moderating role of entrepreneurial-orientation. Journal of Innovation \& Knowledge, 4(3), 171-178. https://doi.org/10.1016/j.jik.2019.02.002

Angrist, J. D., Imbens, G. W., \& Rubin, D. B. (1996). Identification of Causal Effects Using Instrumental Variables. Journal of the American Statistical Association, 91(434), 444455. https://doi.org/10.1080/01621459.1996.10476902

Ayvar Campos, F. J., \& Ochoa Lupián, L. E. (2015). La migración y su influencia en el desarrollo del municipio de Parácuaro, Michoacán Migration and its influence on the development of the municipality of Parácuaro, Michoacán. Revista CIMEXUS, 10(2), 3548.

Azose, J. J., \& Raftery, A. E. (2019). Estimation of emigration, return migration, and transit migration between all pairs of countries. Proceedings of the National Academy of Sciences, 116(1), 116-122. https://doi.org/10.1073/pnas.1722334116

Bucheli, J. R., Fontenla, M., \& Waddell, B. J. (2019). Return migration and violence. World Development, 116, 113-124. https://doi.org/10.1016/j.worlddev.2018.12.010

Caseiro, N., \& Coelho, A. (2019). The influence of Business Intelligence capacity, network learning and innovativeness on startups performance. Journal of Innovation \& Knowledge, 4(3), 139-145. https://doi.org/10.1016/j.jik.2018.03.009 
Cassarino, J.-P. (2004). Theorizing Return Migration: The Conceptual Approach to Return Migrants Revisited. International Journal on Multicultural Societies, 6(2), 253-279.

Castellani, F., \& Lora, E. (2014). Is Entrepreneurship a Chanel of Social Mobility in Latin America? Latin American Journal of Economics, 51(2), 179-194.

Chishti, M., \& Hipsman, F. (2015). In Historic Shift, New Migration Flows from Mexico Fall Below Those from China and India. Migration Policy Institute.

Conover, E., Khamis, M., \& Pearlman, S. (2018). Reversed Migration Trends and Local Labor Markets.

Cruz, M., \& Alfaro, R. S. (2018). Algunos casos de emprendimiento de migrantes retornados. In M. Cruz \& A. Cuecuecha (Eds.), Emprendimiento y Migración de Retorno (pp. 133154). MA Porrúa.

D’Aubeterre Buznego, M. E. (2012). Empezar de nuevo: Migración femenina a Estados Unidos. Retornos y reinserción en la Sierra Norte de Puebla, México. Norteamérica, 7(1), 149180.

David, A. M. (2017). Back to Square One: Socioeconomic Integration of Deported Migrants. International Migration Review, 51(1), 127-154. https://doi.org/10.1111/imre.12208

De Genova, N., \& Peutz, N. (Eds.). (2010). The Deportation Regime: Sovereignty, Space, and the Freedom of Movement. Duke University Press.

De Haas, H. (2010). Migration and Development: A Theoretical Perspective 1. The International Migration Review, 44(1), 227-264. https://doi.org/10.1111/j.1747-7379.2009.00804.x

de Haas, H. (2014). Migration Theory: Quo Vadis? (No. 100; DEMIG Project Paper, pp. 1-39). International Migration Institute \& University of Oxford. 
de Haas, H., Castles, S., \& Miller, M. J. (2019). The Age of Migration: International Population Movements in the Modern World (6th ed.). Palgrave Macmillan.

Démurger, S., \& Xu, H. (2011). Return Migrants: The Rise of New Entrepreneurs in Rural China. World Development, 39(10), 1847-1861.

Dustmann, C. (1999). Temporary Migration, Human Capital, and Language Fluency of Migrants. The Scandinavian Journal of Economics, 101(2), 297-314.

Dustmann, C. (2001). Why Go Back? Return Motives of Migrant Workers (S. Djajie, Ed.; pp. 229-249). Contemporary Economic Policy Issues, vol. 3; London and New York:; Routledge. http://search.ebscohost.com/login.aspx ?direct=true \&db=ecn\&AN=0675535\&site=ehostlive

Dustmann, C., \& Kirchkamp, O. (2002). The Optimal Migration Duration and Activity Choice after Re-migration. Journal of Development Economics, 67(2), 351-372.

Dustmann, C., \& Weiss, Y. (2007). Return Migration: Theory and Empirical Evidence from the UK. British Journal of Industrial Relations, 45(2), 236-256. https://doi.org/10.1111/j.1467-8543.2007.00613.x

Earle, J. S., \& Sakova, Z. (2000). Business start-ups or disguised unemployment? Evidence on the character of self-employment from transition economies. Labour Economics, 7(5), 575-601. https://doi.org/10.1016/S0927-5371(00)00014-2

Fajnzlber, P., Maloney, W. F., \& Rojas, G. M. (2006). Microenterprise dynamics in developing countries: How similar are they to those in the industrialized world? Evidence from Mexico. The World Bank Economic Review, 20(3), 389-419. 
Fernandez-Huertas Moraga, J. (2010). New Evidence on Emigrant Selection. Review of Economics and Statistics, 93(1), 72-96. https://doi.org/10.1162/REST_a_00050

Fichman, M., \& Levinthal, D. A. (1991). Honeymoons and the Liability of Adolescence: A New Perspective on Duration Dependence in Social and Organizational Relationships. The Academy of Management Review, 16(2), 442-468. https://doi.org/10.2307/258870

Findlay, A. M., Li, F. L. N., Jowett, A. J., \& Skeldon, R. (1996). Skilled International Migration and the Global City: A Study of Expatriates in Hong Kong. Transactions of the Institute of British Geographers, 21(1), 49-61.

Fitzgerald, D. (2008). A Nation of Emigrants: How Mexico Manages Its Migration. University of California Press.

Franco, M., \& Prata, M. (2019). Influence of the individual characteristics and personality traits of the founder on the performance of family SMEs. European J. of International Management, 13(1), 41. https://doi.org/10.1504/EJIM.2019.096498

Freeman, J., Carroll, G. R., \& Hannan, M. T. (1983). The Liability of Newness: Age Dependence in Organizational Death Rates. American Sociological Review, 48(5), 692-710. https://doi.org/10.2307/2094928

Garip, F. (2012). Repeat Migration and Remittances as Mechanisms for Wealth Inequality in 119 Communities From the Mexican Migration Project Data. Demography, 49(4), 13351360. https://doi.org/10.1007/s13524-012-0128-6

Garip, F. (2014). The Impact of Migration and Remittances on Wealth Accumulation and Distribution in Rural Thailand. Demography, 51(2), 673-698. https://doi.org/10.1007/s13524-013-0260-y 
Garip, F. (2016). On the Move: Changing Mechanisms of Mexico-U.S. Migration. Princeton University Press.

GEM, G. E. M. C. (2016). Latin America and Caribbean Regional Report 2015/2016. Global Entrepreneurship Monitor. http://www.gemconsortium.org/

Gindling, T. H., \& Newhouse, D. (2014). Self-Employment in the Developing World. World Development, 56, 313-331.

Gonzalez-Barrera, A. (2015). More Mexicans Leaving Than Coming to the U.S. Pew Research Center. http://www.pewhispanic.org/2015/11/19/more-mexicans-leaving-than-coming-tothe-u-s/

Grabowska, I. (2018). Social Skills, Workplaces and Social Remittances: A Case of PostAccession Migrants. Work, Employment and Society, 32(5), 868-886. https://doi.org/10.1177/0950017017719840

Greene, W. H. (2008). Econometric Analysis (6th ed.). Prentice-Hall.

Gruenhagen, J. H., \& Davidsson, P. (2018). Returnee entrepreneurs: Do they all boost emerging economies? International Review of Entrepreneurship, 16(4), Article number: 1589 455488.

Gruenhagen, J. H., Davidsson, P., \& Sawang, S. (2020). Returnee Entrepreneurs: A Systematic Literature Review, Thematic Analysis, and Research Agenda. Foundations and Trends ${ }^{\circledR}$ in Entrepreneurship, 16(4), 310-392. https://doi.org/10.1561/0300000096

Gubert, F., \& Nordman, C. J. (2011). Return Migration and Small Enterprise Development in the Maghreb. In S. Plaza \& D. Ratha (Eds.), Diaspora for Development in Africa (pp. 103126). World Bank. 
Hagan, J. M., Hernández-León, R., \& Demonsant, J. L. (2015). Skills of the Unskilled: Work and Mobility among Mexican Migrants. University of California Press.

Hagan, J. M., \& Wassink, J. (2016). New Skills, New Jobs: Return Migration, Skill Transfers, and Business Formation in Mexico. Social Problems, 63(4), 513-533. http://dx.doi.org/10.1093/socpro/spw021

Hagan, J. M., \& Wassink, J. T. (2020). Return Migration around the World: An Integrated Agenda for Future Research. Annual Review of Sociology, 46.

Hagan, J. M., Wassink, J. T., \& Castro, B. (2019). A Longitudinal Analysis of Resource Mobilization among Forced and Voluntary Return Migrants in Mexico. Journal of Ethnic and Migration Studies, 45(1), 170-189.

Hall, M., Greenman, E., \& Farkas, G. (2010). Legal Status and Wage Disparities for Mexican Immigrants. Social Forces, 89(2), 491-513. https://doi.org/10.1353/sof.2010.0082

Hamdouch, B., \& Wahba, J. (2015). Return migration and entrepreneurship in Morocco. Middle East Development Journal, 7(2), 129-148. https://doi.org/10.1080/17938120.2015.1072696

Hanson, G. H. (2009). The Demography of Mexican Migration to the United States. American Economic Review, 99(2), 22-27.

Hausmann, R., \& Nedelkoska, L. (2018). Welcome home in a crisis: Effects of return migration on the non-migrants' wages and employment. European Economic Review, 101, 101132. https://doi.org/10.1016/j.euroecorev.2017.10.003

Hernández-León, R. (2008). Metropolitan Migrants: The Migration of Urban Mexicans to the United States. University of California Press. 
Hollifield, J., Martin, P. L., \& Orrenius, P. (2014). Controlling Immigration: A Global Perspective, Third Edition. Stanford University Press.

Huerta-Wong, J. E., Burak, E., \& Grusky, D. (2013). Is Mexico the Limiting Case? Social Mobility in the New Gilded Age. In R. Velez, R. Campos, \& J. E. Huerta-Wong (Eds.), Social Mobility in Mexico. Centre for Studies Espiosa Yglesias.

Kumar, P., Bhattacharya, U., \& Nayek, J. Kr. (2014). Return Migration and Development: Evidence from India’s Skilled Professionals. In G. Tejada, U. Bhattacharya, B. Khadria, \& C. Kuptsch (Eds.), Indian Skilled Migration and Development: To Europe and Back (pp. 263-284). Springer India. https://doi.org/10.1007/978-81-322-1810-4_11

Levy, S. (2008). Good Intentions, Bad Outcomes: Social Policy, Informality, and Economic Growth in Mexico. Brookings Institution Press.

Lindstrom, D. P. (1996). Economic Opportunity in Mexico and Return Migration from the United States. Demography, 33(3), 357. https://doi.org/10.2307/2061767

Lindstrom, D. P., \& Lauster, N. (2001). Local Economic Opportunity and the Competing Risks of Internal and U.S. Migration in Zacatecas, Mexico. The International Migration Review, 35(4), 1232-1256.

Lowe, N., Hagan, J. M., \& Iskander, N. (2010). Revealing talent: Informal skills intermediation as an emergent pathway to immigrant labor market incorporation. Environment and Planning A, 42(1), 205-222.

Maloney, W. F. (2004). Informality Revisited. World Development, 32(7), 1159-1178. https://doi.org/10.1016/j.worlddev.2004.01.008 
Mandelman, F. S., \& Montes-Rojas, G. V. (2009). Is Self-employment and Microentrepreneurship a Desired Outcome? World Development, 37(12), 1914-1925. https://doi.org/10.1016/j.worlddev.2009.05.005

Martínez, D. E., Slack, J., \& Martinez-Schuldt, R. D. (2018). Return Migration in the Age of the Unauthorized Permanent Resident: A Quantitative Assessment of Migration Intentions Post-Deportation. International Migration Review, 52(4), 1186-1217.

Masferrer, C., \& Roberts, B. (2012). Going Back Home? Changing Demography and Geography of Mexican Return Migration. Population Research and Policy Review, 31(4), 465-496.

Massey, D. S., Arango, J., Hugo, G., Kouaouci, A., Pellegrino, A., \& Taylor, J. E. (1993). Theories of International Migration: A Review and Appraisal. Population and Development Review, 19(3), 431-466.

Massey, D. S., Durand, J., \& Pren, K. A. (2016). Why Border Enforcement Backfired. American Journal of Sociology, 121(5), 1557-1600. https://doi.org/10.1086/684200

Massey, D. S., Goldring, L., \& Durand, J. (1994). Continuities in Transnational Migration: An Analysis of Nineteen Mexican Communities. American Journal of Sociology, 99(6), 1492-1533. https://doi.org/10.2307/2782582

Massey, D. S., \& Parrado, E. A. (1998). International Migration and Business Formation in Mexico. Social Science Quarterly, 79(1), 1-20.

Massey, D. S., \& Zenteno, R. (2000). A Validation of the Ethnosurvey: The Case of MexicoU.S. Migration. International Migration Review, 34(3), 766-793.

McCarthy, D. J., Puffer, S. M., \& Lamin, A. (2018). Entrepreneurial orientation in a hostile and turbulent environment: Risk and innovativeness among successful Russian entrepreneurs. 
European J. of International Management, 12(1/2), 191.

https://doi.org/10.1504/EJIM.2018.089033

McCormick, B., \& Wahba, J. (2001). Overseas Work Experience, Savings and Entrepreneurship Amongst Return Migrants to LDCs. Scottish Journal of Political Economy, 48(2), 164178. https://doi.org/10.1111/1467-9485.00192

McKenzie, D., Stillman, S., \& Gibson, J. (2010). How Important is Selection? Experimental VS. Non-Experimental Measures of the Income Gains from Migration. Journal of the European Economic Association, 8(4), 913-945. https://doi.org/10.1111/j.15424774.2010.tb00544.x

Medina, D., \& Menjívar, C. (2015). The context of return migration: Challenges of mixed-status families in Mexico's schools. Ethnic and Racial Studies, 38(12), 2123-2139. https://doi.org/10.1080/01419870.2015.1036091

Mesnard, A. (2004). Temporary Migration and Self-Employment: Evidence from Tunisia. Brussels Economic Review/Cahiers Economiques de Bruxelles, 47(1), 119-138.

Mesnard, A., \& Ravallion, M. (2006). The Wealth Effect on New Business Startups in a Developing Economy. Economica, 73(291), 367-392. https://doi.org/10.1111/j.14680335.2006.00515.x

Mezger Kveder, C. L., \& Flahaux, M.-L. (2012). Returning to Dakar: A Mixed Methods Analysis of the Role of Migration Experience for Occupational Status. World Development, 45, 223-238. https://doi.org/10.1016/j.worlddev.2012.11.009

Obschonka, M., Hahn, E., \& Bajwa, N. ul H. (2018). Personal agency in newly arrived refugees: The role of personality, entrepreneurial cognitions and intentions, and career adaptability. Journal of Vocational Behavior, 105, 173-184. https://doi.org/10.1016/j.jvb.2018.01.003 
Parrado, E. A., \& Gutierrez, E. Y. (2016). The Changing Nature of Return Migration to Mexico, 1990-2010. Sociology of Development, 2(2), 93-118. https://doi.org/10.1525/sod.2016.2.2.93

Passel, J., Cohn, D., \& Gonzalez-Barrera, A. (2012). Net Migration from Mexico Falls to Zeroand Perhaps Less. Pew Research Center.

Perry, G. E., Maloney, W. F., Arias, O. S., Fajnzlber, P., Mason, A. D., \& Saavedra-Chanduvi, J. (2007). Informality: Exit and Exclusion. World Bank Publications.

Piracha, M., \& Vadean, F. (2010). Return Migration and Occupational Choice: Evidence from Albania. World Development, 38(8), 1141-1155. https://doi.org/10.1016/j.worlddev.2009.12.015

Portes, A., \& Hoffman, K. (2003). Latin American Class Structures: Their Composition and Change during the Neoliberal Era. Latin American Research Review, 38(1), 41-82.

Ramirez, H., \& Hondagneu-Sotelo, P. (2009). Mexican Immigrant Gardeners: Entrepreneurs or Exploited Workers? Social Problems, 56(1), 70-88. https://doi.org/10.1525/sp.2009.56.1.70

Ravallion, M. (2014). Income inequality in the developing world. Science, 344(6186), 851-855. https://doi.org/10.1126/science.1251875

Rendall, M. S., \& Parker, S. W. (2014). Two Decades of Negative Educational Selectivity of Mexican Migrants to the United States. Population and Development Review, 40(3), 421446. https://doi.org/10.1111/j.1728-4457.2014.00692.x

Roberts, B., Menjívar, C., \& Rodríguez, N. P. (2017). Deportation and Return in a BorderRestricted World: Experiences in Mexico, El Salvador, Guatemala, and Honduras. Springer. 
Romero, M. A. H. (2012). Nothing to Learn? Labor Learning in California's Farmwork. Anthropology of Work Review, 33(2), 73-88.

Sánchez, L. R. (2013). Migración de Retorno y Experiencias de Reinserción en la Zona Metropolitana de la Ciudad De México. Revista Interdisciplinar Da Mobilidade Humana, $21(41), 55-76$.

Sen, A. (1988). Freedom of choice: Concept and content. European Economic Review, 32(2), 269-294. https://doi.org/10.1016/0014-2921(88)90173-0

Sen, A. (1999). Development as Freedom. Anchor Books.

Singer, A., \& Massey, D. S. (1998). The Social Process of Undocumented Border Crossing among Mexican Migrants. International Migration Review, 32(3), 561-592. https://doi.org/10.1177/019791839803200301

Stark, O. (1991). The Migration of Labor. Basil Blackwell.

Stark, O., \& Bloom, D. E. (1985). The New Economics of Labor Migration. The American Economic Review, 75(2), 173-178.

Stark, O., \& Taylor, J. E. (1989). Relative deprivation and international migration. Demography, 26(1), 1-14. https://doi.org/10.2307/2061490

Taylor, J. E. (2004). Remittances, Savings, and Development in Migrant-Sending Areas. In D. S. Massey (Ed.), International Migration: Prospects and Policies in a Global Market. OUP Oxford.

Villarreal, A. (2014). Explaining the Decline in Mexico-U.S. Migration: The Effect of the Great Recession. Demography, 51(6), 2203-2228. https://doi.org/10.1007/s13524-014-0351-4 
Waddell, B. J., \& Fontenla, M. (2015). The Mexican Dream? The effect of return migrants on hometown development. The Social Science Journal, 52(3), 386-396. https://doi.org/10.1016/j.soscij.2015.02.003

Wahba, J., \& Zenou, Y. (2012). Out of sight, out of mind: Migration, entrepreneurship and social capital. Regional Science and Urban Economics, 42(5), 890-903. https://doi.org/10.1016/j.regsciurbeco.2012.04.007

Wassink, J. T. (2018). Is Local Social Development Associated with Workforce Composition? A Municipal Analysis of Mexico, 1990-2015. Population Research and Policy Review, 37(6), 941-966. https://doi.org/10.1007/s11113-018-9490-4

Wassink, J. T., \& Hagan, J. M. (Forthcoming). How Local Community Context Shapes Labor Market Re-Entry and Resource Mobilization among Return Migrants: An Examination of Rural and Urban Communities in Mexico. Journal of Ethnic and Migration Studies.

Wassink, J. T., \& Hagan, J. M. (2018). A Dynamic Model of Self-Employment and Socioeconomic Mobility among Return Migrants: The Case of Urban Mexico. Social Forces, 96(3), 1069-1096.

Williams, A., \& Baláž, V. (2014). International Migration and Knowledge. Routledge. https://doi.org/10.4324/9780203894651

Williams, A. M. (2007). International labour migration and tacit knowledge transactions: A multi-level perspective. Global Networks, 7(1), 29-50.

Williams, A. M., \& Baláž, V. (2005). What Human Capital, Which Migrants? Returned Skilled Migration to Slovakia from the UK. International Migration Review, 39(2), 439-468. 
Woodruff, C., \& Zenteno, R. (2007). Migration networks and microenterprises in Mexico.

Journal of Development Economics, 82(2), 509-528.

https://doi.org/10.1016/j.jdeveco.2006.03.006

Wooldridge, J. M. (2002). Econometric Analysis of Cross Section and Panel Data. MIT Press.

World Bank. (2003). Inequality in Latin America and the Caribbean: Breaking with History?

The World Bank. 


\section{TABLES AND FIGURES}

Table 1 . Summary of study variables by migration status

\begin{tabular}{lcccc}
\hline & All & $\begin{array}{c}\text { non- } \\
\text { migrants }\end{array}$ & $\begin{array}{c}\text { Return } \\
\text { migrants }\end{array}$ & $\begin{array}{c}\text { Mean } \\
\text { test }\end{array}$ \\
\hline $\begin{array}{l}\text { Dependent variable } \\
\text { Became entrepreneur in person-year }\end{array}$ & $0.35 \%$ & $0.34 \%$ & $0.46 \%$ & \\
$\begin{array}{l}\text { Individual characteristics } \\
\text { Age }\end{array}$ & 33.4 & 33.2 & 34.5 & $*$ \\
Years of school & 7.3 & 7.5 & 6.4 & $*$ \\
Married & $77.5 \%$ & $77.1 \%$ & $80.4 \%$ & $*$ \\
Number of children & 3.1 & 3.1 & 2.7 & $*$ \\
Father a US migrant & $3.4 \%$ & $2.6 \%$ & $9.0 \%$ & $*$ \\
$\quad$ \#(properties+land parcels) & 0.74 & 0.73 & 0.80 & $*$ \\
Community characteristics & & & & \\
$\quad$ rancho (0-2,499 inhabitants) & $19.5 \%$ & $19.0 \%$ & $22.7 \%$ & $*$ \\
town (2,500-14,999 inhabitants) & $40.7 \%$ & $39.9 \%$ & $46.2 \%$ & $*$ \\
urban (15,000-99,999 inhabitants) & $22.3 \%$ & $22.1 \%$ & $23.7 \%$ & $*$ \\
$\quad$ metropolitan (100,000+ inhabitants) & $17.5 \%$ & $19.0 \%$ & $7.4 \%$ & $*$ \\
\hline Person-years & 146,372 & 127,914 & 18,458 & $12.6 \%$ \\
Persons & 11,789 & 10,187 & 1,602 & $13.6 \%$ \\
\hline
\end{tabular}

$* p<0.05$, indicates statistical significance of mean comparisons between migrants and non-migrants 
Table 2. Summary of study variables by entrepreneurial status

\begin{tabular}{lccc}
\hline & $\begin{array}{c}\text { Non- } \\
\text { entrepreneur }\end{array}$ & \multicolumn{2}{c}{$\begin{array}{c}\text { Mean } \\
\text { Entrepreneur }\end{array}$} \\
\hline Migrant status & & & \\
$\quad$ Returnee & $12.60 \%$ & $16.38 \%$ & $*$ \\
Individual characteristics & & & \\
$\quad$ Age & 33.4 & 32.3 & $*$ \\
Years of school & 7.3 & 10.4 & $*$ \\
Married & $77.5 \%$ & $77.3 \%$ & \\
Number of children & 3.1 & 2.0 & $*$ \\
Father a US migrant & $3.4 \%$ & $6.7 \%$ & $*$ \\
\#(properties+land parcels) & 0.74 & 0.63 & $*$ \\
Community characteristics & & & \\
rancho (0-2,499 inhabitants) & $19.5 \%$ & $12.9 \%$ & $*$ \\
town (2,500-14,999 inhabitants) & $40.7 \%$ & $32.9 \%$ & $*$ \\
urban (15,000-99,999 inhabitants) & $22.3 \%$ & $33.5 \%$ & $*$ \\
metropolitan (100,000+ inhabitants) & $17.5 \%$ & $20.6 \%$ & \\
\hline Person-years & 145,853 & 519 & \\
\hline
\end{tabular}

$* \mathrm{p}<0.05$, indicates statistical significance of mean comparisons between migrants and nonmigrants 
Table 3 Probit and recursive bivariate probit models predicting entry into entrepreneurship among non-migrants and return migrants

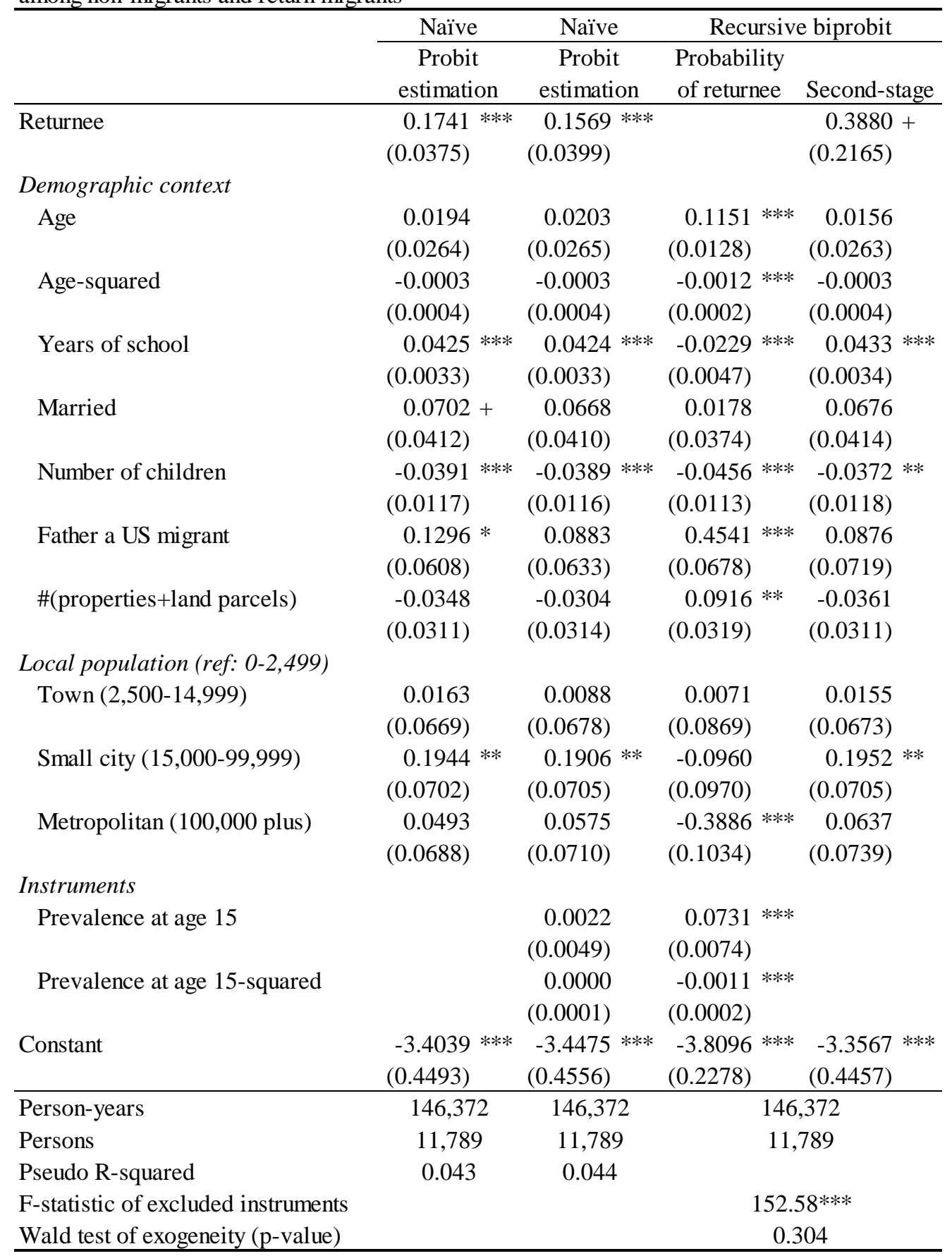

Standard errors clustered at the community-level in parentheses

$+\mathrm{p}<0.1, * \mathrm{p}<0.05, * * \mathrm{p}<0.01, * * * \mathrm{p}<0.001$ 

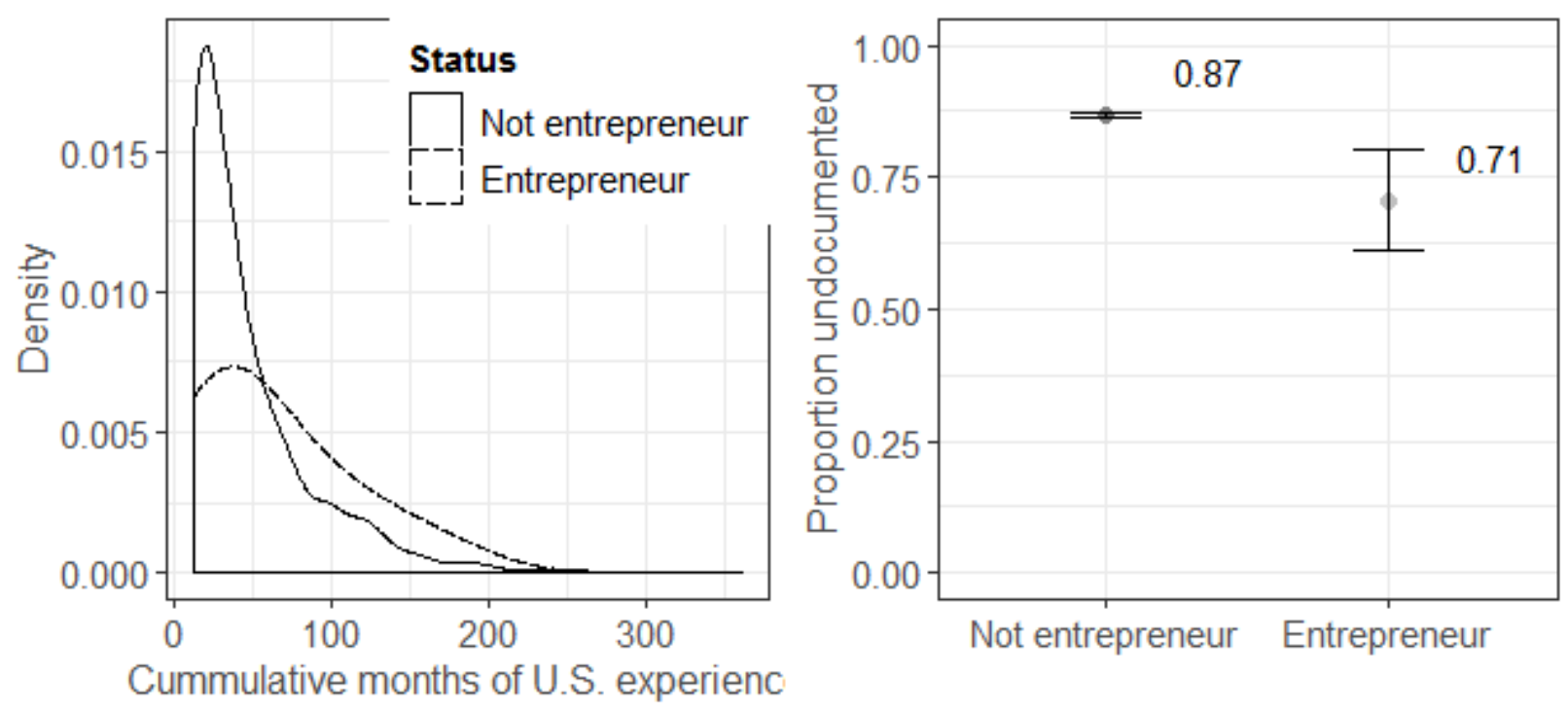

Figure 1. Accumulated months of U.S. experience (left) and proportion undocumented on most recent U.S. trip (right) by entrepreneurial status. 

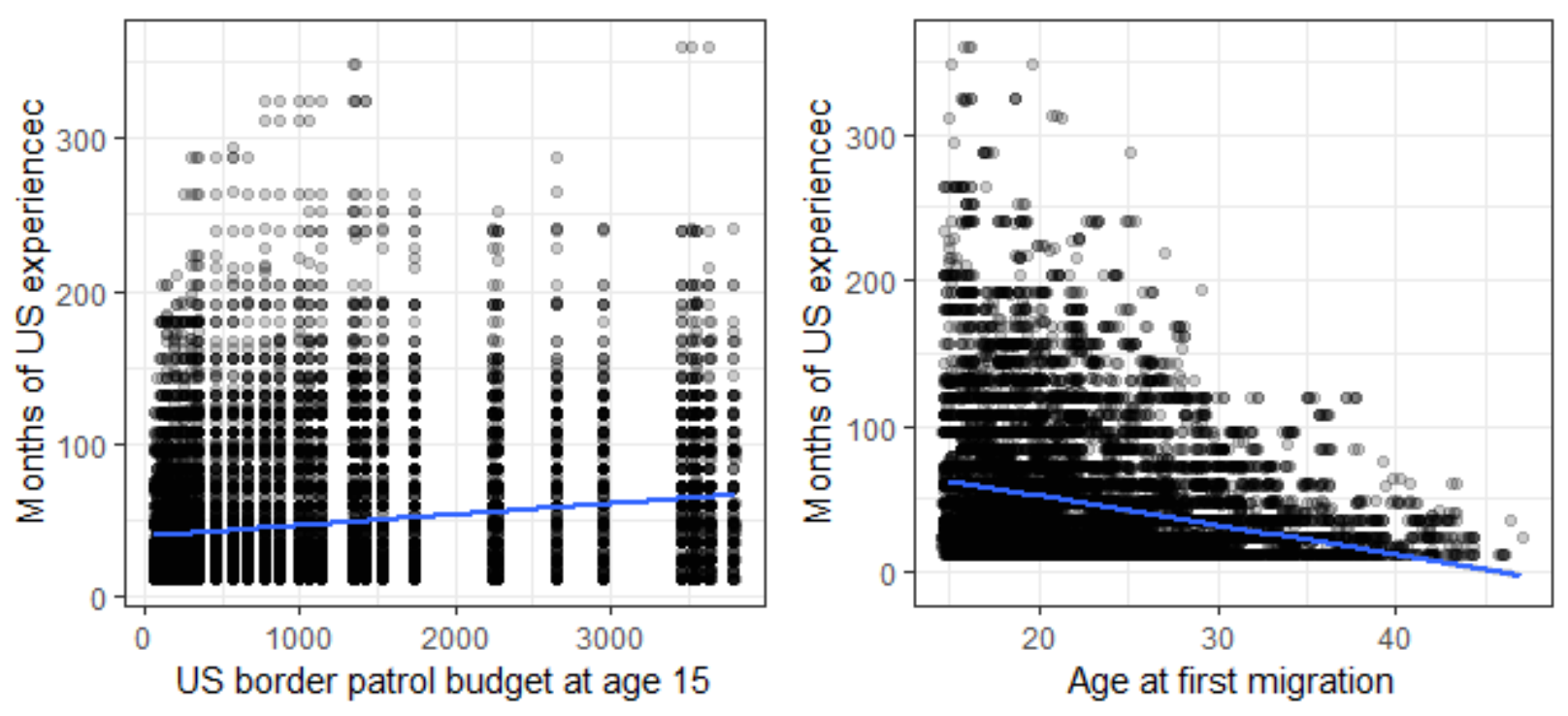

Figure 2. Scatterplots and linear regression lines depicting the bivariate associations between accumulated months of U.S. migration experience and the U.S. border patrol budget at age 15 in millions of U.S. dollars (left) and age at first migration (right). 
Table 4. Naïve and IV-Probit models predicting entry into entrepreneurship among return migrants

\begin{tabular}{|c|c|c|c|c|c|c|}
\hline & \multicolumn{2}{|c|}{ Naïve Probit } & \multicolumn{2}{|c|}{ Naïve Probit } & \multicolumn{2}{|c|}{ IV Probit } \\
\hline & Model 1 & Model 2 & Model3 & Model 4 & $\begin{array}{c}\text { Months of US } \\
\text { experience }\end{array}$ & Entrepreneur \\
\hline \multicolumn{7}{|l|}{ Migration experience } \\
\hline Months of U.S. experience & $\begin{array}{l}0.0026 \text { ** } \\
(0.0008)\end{array}$ & $\begin{array}{l}0.0024 \text { ** } \\
(0.0009)\end{array}$ & $\begin{array}{l}0.0026 \text { ** } \\
(0.0008)\end{array}$ & $\begin{array}{l}0.0026 \text { ** } \\
(0.0008)\end{array}$ & & $\begin{array}{c}0.0036 * \\
(0.0017)\end{array}$ \\
\hline Undocumented & $\begin{array}{l}-0.2999 * * \\
(0.0919)\end{array}$ & $\begin{array}{l}-0.2820 * * \\
(0.0917)\end{array}$ & $\begin{array}{l}-0.2945 * * \\
(0.0911)\end{array}$ & $\begin{array}{l}-0.2865 * * \\
(0.0920)\end{array}$ & $\begin{array}{l}-13.3537 * * * \\
(3.3061)\end{array}$ & $\begin{array}{l}-0.2861 * * \\
(0.0905)\end{array}$ \\
\hline Total US trips & $\begin{array}{r}-0.0151 \\
(0.0226)\end{array}$ & $\begin{array}{r}-0.0205 \\
(0.0233)\end{array}$ & $\begin{array}{r}-0.0151 \\
(0.0225)\end{array}$ & $\begin{array}{r}-0.0155 \\
(0.0224)\end{array}$ & $\begin{array}{l}5.6035 \text { *** } \\
(0.7698)\end{array}$ & $\begin{array}{r}-0.0219 \\
(0.0272)\end{array}$ \\
\hline \multicolumn{7}{|l|}{ Demographic context } \\
\hline Age & $\begin{array}{r}-0.0967 \\
(0.0664)\end{array}$ & $\begin{array}{r}-0.0973 \\
(0.0670)\end{array}$ & $\begin{array}{r}-0.0949 \\
(0.0673)\end{array}$ & $\begin{array}{r}-0.0932 \\
(0.0665)\end{array}$ & $\begin{array}{l}6.7913 \text { *** } \\
(0.9359)\end{array}$ & $\begin{array}{r}-0.1021 \\
(0.0664)\end{array}$ \\
\hline Age-squared & $\begin{array}{r}0.0012 \\
(0.0009)\end{array}$ & $\begin{array}{r}0.0012 \\
(0.0010)\end{array}$ & $\begin{array}{r}0.0012 \\
(0.0010)\end{array}$ & $\begin{array}{r}0.0012 \\
(0.0009)\end{array}$ & $\begin{array}{l}-0.0641 * * * \\
(0.0132)\end{array}$ & $\begin{array}{r}0.0013 \\
(0.0009)\end{array}$ \\
\hline Years of school & $\begin{array}{l}0.0481 \text { *** } \\
(0.0095)\end{array}$ & $\begin{array}{l}0.0498 * * * * \\
(0.0090)\end{array}$ & $\begin{array}{l}0.0484 \text { **** } \\
(0.0096)\end{array}$ & $\begin{array}{l}0.0491 \text { *** } \\
(0.0095)\end{array}$ & $\begin{array}{r}-0.1903 \\
(0.2886)\end{array}$ & $\begin{array}{l}0.0483 \text { **** } \\
(0.0095)\end{array}$ \\
\hline Married & $\begin{array}{r}0.1676 \\
(0.1273)\end{array}$ & $\begin{array}{r}0.1466 \\
(0.1292)\end{array}$ & $\begin{array}{r}0.1644 \\
(0.1268)\end{array}$ & $\begin{array}{r}0.1608 \\
(0.1275)\end{array}$ & $\begin{array}{l}-6.8845 * * \\
(2.1220)\end{array}$ & $\begin{array}{r}0.1766 \\
(0.1260)\end{array}$ \\
\hline Number of children & $\begin{array}{r}-0.0052 \\
(0.0222)\end{array}$ & $\begin{array}{c}-0.0058 \\
(0.0220)\end{array}$ & $\begin{array}{r}-0.0055 \\
(0.0223)\end{array}$ & $\begin{array}{r}-0.0069 \\
(0.0223)\end{array}$ & $\begin{array}{l}-4.2168 \text { *** } \\
(0.5661)\end{array}$ & $\begin{array}{r}-0.0005 \\
(0.0242)\end{array}$ \\
\hline Father a US migrant & $\begin{array}{r}-0.0166 \\
(0.1017)\end{array}$ & $\begin{array}{r}-0.0470 \\
(0.1029)\end{array}$ & $\begin{array}{r}-0.0215 \\
(0.1065)\end{array}$ & $\begin{array}{r}-0.0340 \\
(0.1068)\end{array}$ & $\begin{array}{l}10.1606 * * \\
(3.8374)\end{array}$ & $\begin{array}{r}-0.0280 \\
(0.1024)\end{array}$ \\
\hline$\#$ (properties+land parcels) & $\begin{array}{r}-0.0303 \\
(0.0607)\end{array}$ & $\begin{array}{r}-0.0142 \\
(0.0604)\end{array}$ & $\begin{array}{r}-0.2800 \\
(0.0612)\end{array}$ & $\begin{array}{c}-0.0229 \\
(0.0612)\end{array}$ & $\begin{array}{r}1.8996 \\
(1.4828)\end{array}$ & $\begin{array}{r}-0.0332 \\
(0.0599)\end{array}$ \\
\hline \multicolumn{7}{|l|}{ Local population (ref: 0-2,499) } \\
\hline Town $(2,500-14,999)$ & $\begin{array}{r}0.0916 \\
(0.1032)\end{array}$ & $\begin{array}{r}0.0802 \\
(0.1024)\end{array}$ & $\begin{array}{r}0.0905 \\
(0.1029)\end{array}$ & $\begin{array}{r}0.0903 \\
(0.1028)\end{array}$ & $\begin{array}{r}2.7864 \\
(2.6262)\end{array}$ & $\begin{array}{r}0.0868 \\
(0.1036)\end{array}$ \\
\hline Small city $(15,000-99,999)$ & $\begin{array}{c}0.2591 * \\
(0.1039)\end{array}$ & $\begin{array}{c}0.2457 * \\
(0.1039)\end{array}$ & $\begin{array}{c}0.2565 * \\
(0.1035)\end{array}$ & $\begin{array}{l}0.2518 * \\
(0.1038)\end{array}$ & $\begin{array}{r}3.1542 \\
(2.3076)\end{array}$ & $\begin{array}{c}0.2548 * \\
(0.1035)\end{array}$ \\
\hline Metropolitan (100,000 plus) & $\begin{array}{r}0.1015 \\
(0.1505)\end{array}$ & $\begin{array}{r}0.0616 \\
(0.1513)\end{array}$ & $\begin{array}{r}0.0945 \\
(0.1503)\end{array}$ & $\begin{array}{r}0.0846 \\
(0.1526)\end{array}$ & $\begin{array}{r}-4.9285 \\
(3.1691)\end{array}$ & $\begin{array}{r}0.1072 \\
(0.1513)\end{array}$ \\
\hline \multicolumn{7}{|l|}{ Instruments } \\
\hline Age at first $*$ budget at 15 & & $\begin{array}{r}-0.0001 \\
(0.0001)\end{array}$ & & & $\begin{array}{l}-0.0126 \text { *** } \\
(0.0013)\end{array}$ & \\
\hline Border patrol budget at 15 & & $\begin{array}{r}0.0012 \\
(0.0011)\end{array}$ & & & $\begin{array}{l}0.2681 * * * \\
(0.0272)\end{array}$ & \\
\hline \multicolumn{7}{|l|}{ Period (ref: 1975-1985) } \\
\hline 1986-2001 & & & $\begin{array}{r}-0.0221 \\
(0.1205)\end{array}$ & & & \\
\hline 2001-2017 & & & $\begin{array}{r}-0.0572 \\
(0.1597)\end{array}$ & & & \\
\hline Year of observation & & & & $\begin{array}{r}-0.0042 \\
(0.0051)\end{array}$ & & \\
\hline Constant & $\begin{array}{r}-1.2374 \\
(1.1424) \\
\end{array}$ & $\begin{array}{r}-1.1067 \\
(1.1544) \\
\end{array}$ & $\begin{array}{r}-1.2600 \\
(1.1514) \\
\end{array}$ & $\begin{array}{r}7.0056 \\
(10.1914) \\
\end{array}$ & $\begin{array}{l}-92.8386 * * * \\
(15.9223)\end{array}$ & $\begin{array}{r}-1.1745 \\
(1.1391) \\
\end{array}$ \\
\hline Person-years & 18,458 & 18,458 & 18,458 & 18,458 & 18,4 & 458 \\
\hline Persons & 1,602 & 1,602 & 1,602 & 1,602 & & \\
\hline Pseudo R-squared & 0.053 & 0.058 & 0.053 & 0.054 & & \\
\hline F-statistic of excluded instruments & & & & & 49.82 & $2 * * *$ \\
\hline Wald test of exogeneity (p-value) & & & & & & \\
\hline
\end{tabular}

Standard errors clustered at the community-level in parentheses

$+\mathrm{p}<0.1, * \mathrm{p}<0.05, * * \mathrm{p}<0.01, * * * \mathrm{p}<0.001$ 
Table A1 Probit and recursive bivariate probit models, adjusted, for the prevalence of entrepreneurship, that predict entry into entrepreneurship among non-migrants and return migrants

\begin{tabular}{|c|c|c|c|c|}
\hline & \multirow{2}{*}{$\begin{array}{c}\text { Naïve } \\
\text { Probit } \\
\text { estimation }\end{array}$} & \multirow{2}{*}{$\begin{array}{c}\text { Naïve } \\
\begin{array}{c}\text { Probit } \\
\text { estimation }\end{array}\end{array}$} & \multicolumn{2}{|c|}{ Recursive biprobit } \\
\hline & & & $\begin{array}{c}\text { Probability } \\
\text { of returnee }\end{array}$ & Second-stage \\
\hline Returnee & $\begin{array}{l}0.1871 \text { *** } \\
(0.0374)\end{array}$ & $\begin{array}{l}0.1618 \text { *** } \\
(0.0404)\end{array}$ & & $\begin{array}{c}0.4613 * \\
(0.1886)\end{array}$ \\
\hline \multicolumn{5}{|l|}{ Demographic context } \\
\hline Age & $\begin{array}{r}0.0255 \\
(0.0267)\end{array}$ & $\begin{array}{r}0.0269 \\
(0.0268)\end{array}$ & $\begin{array}{l}0.1128 \text { **** } \\
(0.0077)\end{array}$ & $\begin{array}{r}0.0211 \\
(0.0276)\end{array}$ \\
\hline Age-squared & $\begin{array}{r}-0.0004 \\
(0.0004)\end{array}$ & $\begin{array}{r}-0.0004 \\
(0.0004)\end{array}$ & $\begin{array}{l}-0.0012 \text { *** } \\
(0.0001)\end{array}$ & $\begin{array}{r}-0.0003 \\
(0.0004)\end{array}$ \\
\hline Years of school & $\begin{array}{l}0.0430 \text { *** } \\
(0.0032)\end{array}$ & $\begin{array}{l}0.0430 \text { *** } \\
(0.0032)\end{array}$ & $\begin{array}{l}-0.0234 \text { *** } \\
(0.0011)\end{array}$ & $\begin{array}{l}0.0440 \text { *** } \\
(0.0033)\end{array}$ \\
\hline Married & $\begin{array}{c}0.0727+ \\
(0.0418)\end{array}$ & $\begin{array}{r}0.0671 \\
(0.0416)\end{array}$ & $\begin{array}{r}0.0191 \\
(0.0117)\end{array}$ & $\begin{array}{c}0.0696+ \\
(0.0395)\end{array}$ \\
\hline Number of children & $\begin{array}{l}-0.0392 \text { *** } \\
(0.0115)\end{array}$ & $\begin{array}{l}-0.0393 \text { *** } \\
(0.0115)\end{array}$ & $\begin{array}{l}-0.0458 * * * \\
(0.0028)\end{array}$ & $\begin{array}{l}-0.0368 * * \\
(0.0116)\end{array}$ \\
\hline Father a US migrant & $\begin{array}{l}0.1379 * \\
(0.0607)\end{array}$ & $\begin{array}{r}0.0864 \\
(0.0631)\end{array}$ & $\begin{array}{l}0.4525 \text { *** } \\
(0.0203)\end{array}$ & $\begin{array}{r}0.0863 \\
(0.0726)\end{array}$ \\
\hline \#(properties+land parcels) & $\begin{array}{r}-0.0236 \\
(0.0310)\end{array}$ & $\begin{array}{r}-0.0166 \\
(0.0314)\end{array}$ & $\begin{array}{l}0.0856 \text { *** } \\
(0.0076)\end{array}$ & $\begin{array}{r}-0.0248 \\
(0.0271)\end{array}$ \\
\hline \multicolumn{5}{|l|}{ Local population (ref: 0-2,499) } \\
\hline Town $(2,500-14,999)$ & $\begin{array}{r}0.0286 \\
(0.0615)\end{array}$ & $\begin{array}{r}0.0215 \\
(0.0637)\end{array}$ & $\begin{array}{r}0.0080 \\
(0.0119)\end{array}$ & $\begin{array}{r}0.0278 \\
(0.0479)\end{array}$ \\
\hline Small city $(15,000-99,999)$ & $\begin{array}{l}0.1947 \text { ** } \\
(0.0662)\end{array}$ & $\begin{array}{l}0.1867 \text { ** } \\
(0.0668)\end{array}$ & $\begin{array}{l}-0.0876 \text { *** } \\
(0.0136)\end{array}$ & $\begin{array}{l}0.1960 \text { *** } \\
(0.0489)\end{array}$ \\
\hline Metropolitan (100,000 plus) & $\begin{array}{r}0.0485 \\
(0.0631)\end{array}$ & $\begin{array}{r}0.0594 \\
(0.0660)\end{array}$ & $\begin{array}{l}-0.3886 \text { *** } \\
(0.0170)\end{array}$ & $\begin{array}{r}0.0659 \\
(0.0545)\end{array}$ \\
\hline Prevalence of entrepreneurship & $\begin{array}{l}0.5906 \text { *** } \\
(0.1410)\end{array}$ & $\begin{array}{l}0.6304 \text { *** } \\
(0.1405)\end{array}$ & $\begin{array}{l}-0.3816 \text { *** } \\
(0.0375)\end{array}$ & $\begin{array}{l}0.6199 \text { *** } \\
(0.1178)\end{array}$ \\
\hline \multicolumn{5}{|l|}{ Instruments } \\
\hline Prevalence at age 15 & & $\begin{array}{r}0.0064 \\
(0.0046)\end{array}$ & $\begin{array}{l}0.0711 \text { *** } \\
(0.0011)\end{array}$ & \\
\hline Prevalence at age 15 -squared & & $\begin{array}{r}0.0000 \\
(0.0001)\end{array}$ & $\begin{array}{l}-0.0010 \text { *** } \\
(0.0000)\end{array}$ & \\
\hline Constant & $\begin{array}{l}-3.6925 \text { *** } \\
(0.4562)\end{array}$ & $\begin{array}{l}-3.7799 \text { *** } \\
(0.4620)\end{array}$ & $\begin{array}{l}-3.6591 * * * \\
(0.1347)\end{array}$ & $\begin{array}{l}-3.6465 * * * \\
(0.4714)\end{array}$ \\
\hline Person-years & 146,372 & 146,372 & & 372 \\
\hline Persons & 11,789 & 11,789 & & 789 \\
\hline Pseudo R-squared & 0.047 & 0.048 & & \\
\hline F-statistic of excluded instruments & & & 131.6 & $60 * * *$ \\
\hline Wald test of exogeneity (p-value) & & & & 116 \\
\hline
\end{tabular}

Standard errors clustered at the community-level in parentheses

$+\mathrm{p}<0.1, * \mathrm{p}<0.05, * * \mathrm{p}<0.01, * * * \mathrm{p}<0.001$ 
Table A2. Naïve and IV-Probit models adjusted for the rate of entrepreneurship that predict entry into entrepreneurship among return migrants

\begin{tabular}{|c|c|c|c|c|c|c|}
\hline & \multicolumn{2}{|c|}{ Naïve Probit } & \multicolumn{2}{|c|}{ Naïve Probit } & \multicolumn{2}{|c|}{ IV Probit } \\
\hline & Model 1 & Model 2 & Model3 & Model 4 & $\begin{array}{c}\text { Months of US } \\
\text { experience }\end{array}$ & Entrepreneur \\
\hline \multicolumn{7}{|l|}{ Migration experience } \\
\hline Months of U.S. experience & $\begin{array}{l}0.0026 \text { ** } \\
(0.0008)\end{array}$ & $\begin{array}{l}0.0024 \text { ** } \\
(0.0009)\end{array}$ & $\begin{array}{l}0.0025 \text { ** } \\
(0.0008)\end{array}$ & $\begin{array}{l}0.0026 \text { ** } \\
(0.0008)\end{array}$ & & $\begin{array}{l}0.0045 * \\
(0.0021)\end{array}$ \\
\hline Undocumented & $\begin{array}{l}-0.2903 \text { ** } \\
(0.0926)\end{array}$ & $\begin{array}{l}-0.2842 \text { ** } \\
(0.0927)\end{array}$ & $\begin{array}{l}-0.3106 \text { *** } \\
(0.0916)\end{array}$ & $\begin{array}{l}-0.3040 \text { ** } \\
(0.0933)\end{array}$ & $\begin{array}{l}-13.3392 \\
(3.2961) * * *\end{array}$ & $\begin{array}{l}-0.2651 \\
(0.0931)\end{array}$ \\
\hline Total US trips & $\begin{array}{l}-0.0118 \\
(0.0225)\end{array}$ & $\begin{array}{l}-0.0148 \\
(0.0229)\end{array}$ & $\begin{array}{l}-0.0120 \\
(0.0227)\end{array}$ & $\begin{array}{l}-0.0114 \\
(0.0226)\end{array}$ & $\begin{array}{c}5.6198 \\
(0.7675) * * * *\end{array}$ & $\begin{array}{r}-0.0237 \\
(0.0279)\end{array}$ \\
\hline \multicolumn{7}{|l|}{ Demographic context } \\
\hline Age & $\begin{array}{r}-0.0720 \\
(0.0688)\end{array}$ & $\begin{array}{r}-0.0710 \\
(0.0692)\end{array}$ & $\begin{array}{r}-0.0836 \\
(0.0697)\end{array}$ & $\begin{array}{c}-0.0752 \\
(0.0689)\end{array}$ & $\begin{array}{c}6.8881 \\
(0.9385)\end{array}$ **** & $\begin{array}{r}-0.0823 \\
(0.0691)\end{array}$ \\
\hline Age-squared & $\begin{array}{r}0.0010 \\
(0.0010)\end{array}$ & $\begin{array}{r}0.0010 \\
(0.0010)\end{array}$ & $\begin{array}{r}0.0011 \\
(0.0010)\end{array}$ & $\begin{array}{r}0.0010 \\
(0.0010)\end{array}$ & $\begin{array}{l}-0.0650 \\
(0.0133) * * *\end{array}$ & $\begin{array}{r}0.0011 \\
(0.0010)\end{array}$ \\
\hline Years of school & $\begin{array}{l}0.0432 \text { **** } \\
(0.0085)\end{array}$ & $\begin{array}{l}0.0441 \text { *** } \\
(0.0082)\end{array}$ & $\begin{array}{l}0.0415 \text { *** } \\
(0.0089)\end{array}$ & $\begin{array}{l}0.0419 * * * \\
(0.0090)\end{array}$ & $\begin{array}{r}-0.2168 \\
(0.2905)\end{array}$ & $\begin{array}{l}0.0435 \text { *** } \\
(0.0086)\end{array}$ \\
\hline Married & $\begin{array}{r}0.1795 \\
(0.1299)\end{array}$ & $\begin{array}{r}0.1703 \\
(0.1305)\end{array}$ & $\begin{array}{r}0.1864 \\
(0.1274)\end{array}$ & $\begin{array}{r}0.1869 \\
(0.1284)\end{array}$ & $\begin{array}{l}-6.8006 \\
(2.1238) * *\end{array}$ & $\begin{array}{r}0.1949 \\
(0.1277)\end{array}$ \\
\hline Number of children & $\begin{array}{l}-0.0092 \\
(0.0238)\end{array}$ & $\begin{array}{l}-0.0096 \\
(0.0236)\end{array}$ & $\begin{array}{r}-0.0083 \\
(0.0241)\end{array}$ & $\begin{array}{l}-0.0076 \\
(0.0242)\end{array}$ & $\begin{array}{l}-4.2168 \\
(0.5613) * * *\end{array}$ & $\begin{array}{r}-0.0008 \\
(0.0259)\end{array}$ \\
\hline Father a US migrant & $\begin{array}{r}0.0259 \\
(0.1001)\end{array}$ & $\begin{array}{r}0.0109 \\
(0.1008)\end{array}$ & $\begin{array}{r}0.0505 \\
(0.1044)\end{array}$ & $\begin{array}{r}0.0463 \\
(0.1049)\end{array}$ & $\begin{array}{l}10.3940 \\
(3.8257) * *\end{array}$ & $\begin{array}{r}0.0058 \\
(0.1024)\end{array}$ \\
\hline \#(properties+land parcels) & $\begin{array}{r}0.0079 \\
(0.0600)\end{array}$ & $\begin{array}{r}0.0129 \\
(0.0603)\end{array}$ & $\begin{array}{r}0.0047 \\
(0.0616)\end{array}$ & $\begin{array}{r}0.0030 \\
(0.0617)\end{array}$ & $\begin{array}{r}2.0339 \\
(1.4865)\end{array}$ & $\begin{array}{r}0.0027 \\
(0.0591)\end{array}$ \\
\hline \multicolumn{7}{|l|}{ Local population (ref: 0-2,499) } \\
\hline Town $(2,500-14,999)$ & $\begin{array}{r}0.1101 \\
(0.1032)\end{array}$ & $\begin{array}{r}0.0994 \\
(0.1020)\end{array}$ & $\begin{array}{r}0.1184 \\
(0.1054)\end{array}$ & $\begin{array}{r}0.1161 \\
(0.1056)\end{array}$ & $\begin{array}{r}2.8149 \\
(2.5920)\end{array}$ & $\begin{array}{r}0.1024 \\
(0.1044)\end{array}$ \\
\hline Small city $(15,000-99,999)$ & $\begin{array}{l}0.2363 * \\
(0.1024)\end{array}$ & $\begin{array}{l}0.2282 * \\
(0.1015)\end{array}$ & $\begin{array}{l}0.2474 * \\
(0.1043)\end{array}$ & $\begin{array}{l}0.2460 * \\
(0.1050)\end{array}$ & $\begin{array}{r}2.9875 \\
(2.3190)\end{array}$ & $\begin{array}{l}0.2290 * \\
(0.1021)\end{array}$ \\
\hline Metropolitan (100,000 plus) & $\begin{array}{r}0.1571 \\
(0.1435)\end{array}$ & $\begin{array}{r}0.1365 \\
(0.1439)\end{array}$ & $\begin{array}{r}0.1781 \\
(0.1460)\end{array}$ & $\begin{array}{r}0.1777 \\
(0.1485)\end{array}$ & $\begin{array}{r}-4.2952 \\
(3.1860)\end{array}$ & $\begin{array}{r}0.1668 \\
(0.1458)\end{array}$ \\
\hline Prevalence of entrepreneurship & $\begin{array}{l}0.9091 \text { *** } \\
(0.1221)\end{array}$ & $\begin{array}{l}0.8736 \text { *** } \\
(0.1246)\end{array}$ & $\begin{array}{l}0.9704 \text { *** } \\
(0.1269)\end{array}$ & $\begin{array}{l}0.9494 * * * \\
(0.1284)\end{array}$ & $\begin{array}{c}6.9788 \\
(3.7920)+\end{array}$ & $\begin{array}{l}0.8959 * * * \\
(0.1209)\end{array}$ \\
\hline \multicolumn{7}{|l|}{ Instruments } \\
\hline Age at first $*$ budget at 15 & & $\begin{array}{l}-0.0001 \\
(0.0001)\end{array}$ & & & $\begin{array}{l}-0.0125 \\
(0.0013) * * *\end{array}$ & \\
\hline Border patrol budget at 15 & & $\begin{array}{r}0.0011 \\
(0.0010)\end{array}$ & & & $\begin{array}{c}0.2670 \\
(0.0273) * * *\end{array}$ & \\
\hline \multicolumn{7}{|l|}{ Period (ref: 1975-1985) } \\
\hline 1986-2001 & & & $\begin{array}{r}0.1458 \\
(0.1215)\end{array}$ & & & \\
\hline 2001-2017 & & & $\begin{array}{r}0.2189 \\
(0.1677)\end{array}$ & & & \\
\hline Year of observation & & & & $\begin{array}{r}0.0044 \\
(0.0053)\end{array}$ & & \\
\hline Constant & $\begin{array}{l}-2.0129+ \\
(1.1976)\end{array}$ & $\begin{array}{r}-1.9643 \\
(1.2080)\end{array}$ & $\begin{array}{r}-1.9092 \\
(1.2050)\end{array}$ & $\begin{array}{r}-10.6622 \\
(10.3878)\end{array}$ & $\begin{array}{l}-96.7226 \text { **** } \\
(15.9255)\end{array}$ & $\begin{array}{r}-1.8837 \\
(1.1952)\end{array}$ \\
\hline Person-years & 18,458 & 18,458 & 18,458 & 18,458 & & 458 \\
\hline Persons & 1,602 & 1,602 & 1,602 & 1,602 & 1,6 & 02 \\
\hline Pseudo R-squared & 0.084 & 0.085 & 0.085 & 0.084 & & \\
\hline F-statistic of excluded instruments & & & & & 48.92 & $2 * * *$ \\
\hline Wald test of exogeneity (p-value) & & & & & 0.3 & 53 \\
\hline
\end{tabular}

